Old Dominion University

ODU Digital Commons

OEAS Faculty Publications

Ocean, Earth \& Atmospheric Sciences

2006

\title{
Evaluating the Biogeochemical Cycle of Selenium in San Francisco Bay Through Modeling
}

Shannon L. Meseck

Gregory A. Cutter

Old Dominion University, gcutter@odu.edu

Follow this and additional works at: https://digitalcommons.odu.edu/oeas_fac_pubs

Part of the Biogeochemistry Commons, Marine Biology Commons, and the Oceanography Commons

\section{Repository Citation}

Meseck, Shannon L. and Cutter, Gregory A., "Evaluating the Biogeochemical Cycle of Selenium in San Francisco Bay Through Modeling" (2006). OEAS Faculty Publications. 51.

https://digitalcommons.odu.edu/oeas_fac_pubs/51

\section{Original Publication Citation}

Meseck, S.L., \& Cutter, G.A. (2006). Evaluating the biogeochemical cycle of selenium in San Francisco Bay through modeling. Limnology and Oceanography, 51(5), 2018-2032. doi: 10.4319/lo.2006.51.5.2018

This Article is brought to you for free and open access by the Ocean, Earth \& Atmospheric Sciences at ODU Digital Commons. It has been accepted for inclusion in OEAS Faculty Publications by an authorized administrator of ODU Digital Commons. For more information, please contact

digitalcommons@odu.edu. 


\title{
Evaluating the biogeochemical cycle of selenium in San Francisco Bay through modeling
}

\author{
Shannon L. Meseck ${ }^{1}$ and Gregory A. Cutter
}

Old Dominion University, Department of Ocean, Earth, and Atmospheric Sciences, Norfolk, Virginia 23529

\begin{abstract}
A biogeochemical model was developed to simulate salinity, total suspended material, phytoplankton biomass, dissolved selenium concentrations (selenite, selenate, and organic selenide), and particulate selenium concentrations (selenite + selenate, elemental selenium, and organic selenide) in the San Francisco Bay estuary. Model-generated estuarine profiles of total dissolved selenium reproduced observed estuarine profiles at a confidence interval of $91-99 \%$ for 8 different years under various environmental conditions. The model accurately reproduced the observed dissolved speciation at confidence intervals of $81-98 \%$ for selenite, $72-91 \%$ for selenate, and $60-96 \%$ for organic selenide. For particulate selenium, model-simulated estuarine profiles duplicated the observed behavior of total particulate selenium (76-93\%), elemental selenium (80-97\%), selenite + selenate (77-82\%), and organic selenide (70-83\%). Discrepancies between model simulations and the observed data provided insights into the estuarine biogeochemical cycle of selenium that were largely unknown (e.g., adsorption/desorption). Forecasting simulations investigated how an increase in the discharge from the San Joaquin River and varying refinery inputs affect total dissolved and particulate selenium within the estuary. These model runs indicate that during high river flows the refinery signal is undetectable, but when river flow is low (70day residence time) total particle-associated selenium concentrations can increase to $>2 \mu \mathrm{g} \mathrm{g}^{-1}$. Increasing the San Joaquin River discharge could also increase the total particle-associated selenium concentrations to $>1 \mu \mathrm{g} \mathrm{g}^{-1}$. For both forecasting simulations, particle-associated selenium was predicted to be higher than current conditions and reached levels where selenium could accumulate in the estuarine food web.
\end{abstract}

Extensive research has been done on modeling how physical, biological, or chemical parameters in an estuary individually affect the distribution and speciation of a trace element (e.g., Paucot and Wollast 1997; Mwanuzi and De Smedt 1999), but little work has been done using models to simulate the complete biogeochemical cycle of a trace element (i.e., coupling physical, biological, and chemical processes). With recent advances in estuarine modeling, more extensive simulations of biogeochemical cycles of an element are now possible. Coupling empirical observations with modeling enables estuarine processes to be more completely elucidated than using either approach individually. In this respect, selenium presents some compelling reasons for use as the "test" element. Human activities (e.g., irrigation, petroleum refining, power production, and mining), have increased the input of selenium to some aquatic systems. This mobilization has been implicated in elevated concentrations of selenium in waterfowl, fish, and bivalves of some estuaries like the San Francisco Bay (Ohlendorf et al. 1986).

Selenium exists in four oxidation states (II, 0, IV, and $\mathrm{VI}$ ), and in different chemical forms (i.e., organic and

1 Present address: U.S. Department of Commerce/National Oceanic \& Atmospheric Administration/National Marine Fisheries Service, 212 Rogers Avenue, Milford, Connecticut 06460.

\section{Acknowledgments}

We thank Lynda Cutter and Martina Doblin for sampling and providing the dissolved and particulate selenium speciation data, and Robin Stewart of U.S. Geological Survey for the acquisition and processing of refinery samples.

This project was supported by funds from the National Science Foundation Environmental Geochemistry and Biogeochemistry (EBG) Program (OCE-9707946 to G.A.C.) and CALFED (982015000-00096). inorganic) within these oxidation states. In oxygenated marine and fresh waters, dissolved selenium is found as selenite ( $\mathrm{Se}+\mathrm{IV}$, ca. $35 \%$ of the total selenium; Measures et al. 1980), selenate (Se+VI), and organic selenides (Se-II), with some of the organic species as selenium-containing amino acids and peptides (Cutter and Bruland 1984) and methylated forms (Cooke and Bruland 1987). Significantly, the biotic uptake and toxicity of dissolved selenium depends not only on its concentration, but also on its chemical speciation (Riedel et al. 1996). Thus, any modeling efforts with selenium must include the capability for accurate speciation predictions.

The biogeochemical cycle of dissolved selenium in estuarine waters (Takayanagi and Cossa 1985; Cutter 1989; Cutter and Cutter 2004) and sediments (Belzile and Lebel 1988; Velinsky and Cutter 1991) and its bioavailability in the food web (Doblin et al. 1999) have all been examined. The biogeochemical cycle of dissolved selenium in an estuary (Fig. 1) includes inputs via rivers, anthropogenic sources, and exchange with the open ocean. Advection and diffusion move selenium through the estuary, while internal transformations occur through biotic and abiotic reactions during transport. The transformation reactions (biotic and abiotic) include the oxidation of dissolved organic selenide to selenite and selenite to selenate. Biotic reactions affecting selenium in an estuary include dissolved selenite, selenate, and organic selenide uptake by phytoplankton, and incorporation into various biochemical components (Fig. 1).

The sources of particulate selenium to an estuary are particles from rivers (biogenic and mineral detritus), biogenic particles produced in the water column (phytoplankton detritus), and sediment resuspension. Suspended particulate organic selenide can undergo remineralization 


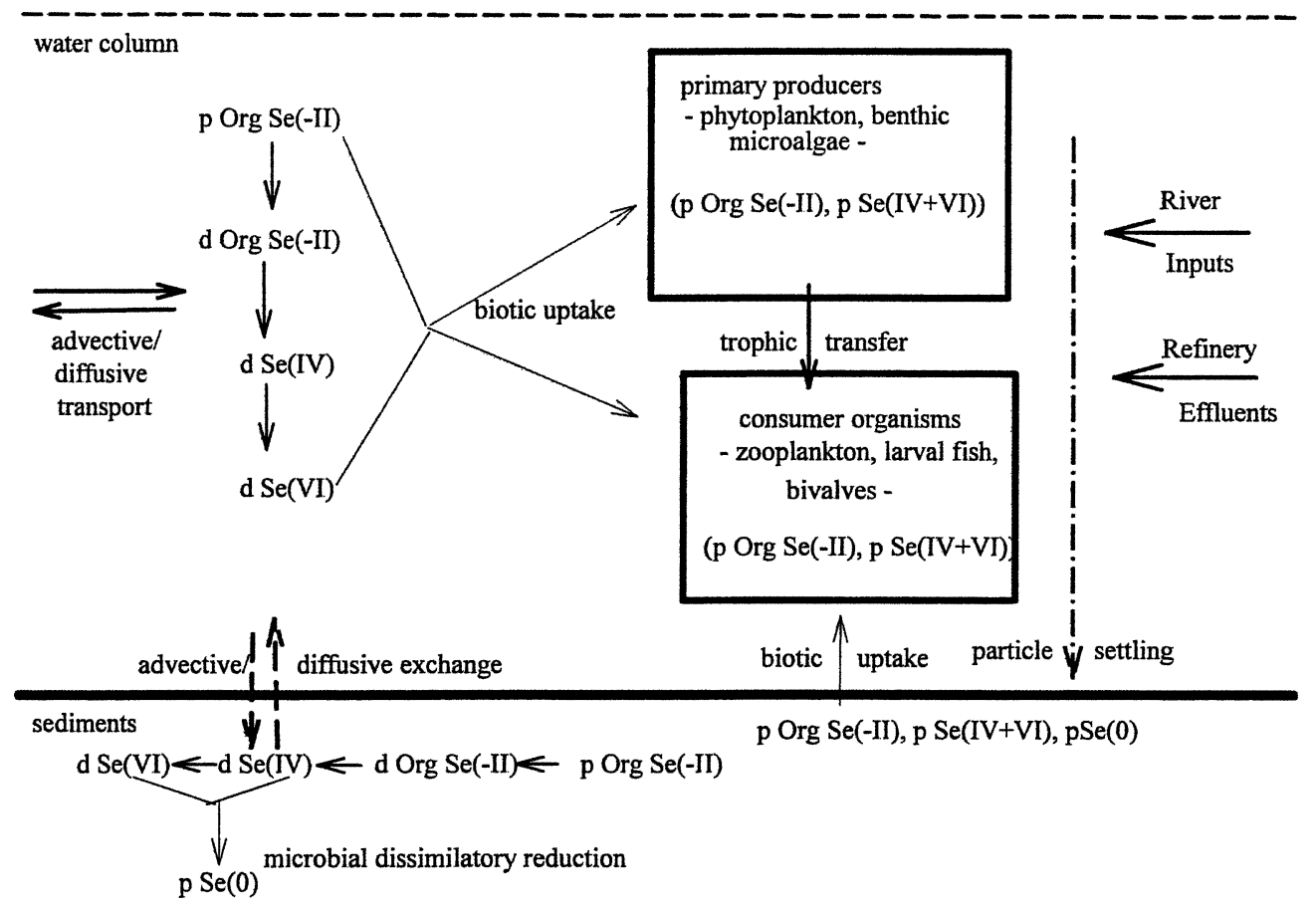

Fig. 1. Conceptual diagram of selenium's biogeochemical cycle in the San Francisco Bay estuary, with the major chemical speciation of particulate selenium in primary producers and consumer organisms indicated in brackets. Arrows represent fluxes or transformations; $p$ is particulate, and $\mathrm{d}$ is dissolved.

to dissolved organic selenide or it can sink and become part of the sedimentary record (Fig. 1). In sediments, particulate selenium can undergo a variety of oxidation-reduction reactions that may cause selenium to become mobile or permanently buried (Velinsky and Cutter 1991). For example, particulate selenium in the bed of an estuary can undergo regeneration to dissolved organic selenide. In this way, sediments can become a source of dissolved selenium to the estuary via pore-water exchange with the overlying water. A biogeochemical model of selenium needs to include all of the processes in Fig. 1, including physical forcing (tidal and riverine transport, resuspension) that moves it through an estuary. Such a model can be used to test or evaluate the understanding of this complex cycle (e.g., the relative importance of phytoplankton versus sediment resuspension in controlling suspended particulate selenium).

Selenium concentrations in the particulate (Doblin et al. 2006), dissolved (Cutter 1989; Cutter and Cutter 2004), and sedimentary phases (Meseck and Cutter unpubl. data) have been determined in the San Francisco Bay estuary. These studies were conducted during a 16-year time period and provide data that were used to construct a biogeochemical model of selenium in the estuary based on Fig. 1. This article describes the model and its performance with past and present-day data (so-called "validation") and then presents future simulations of dissolved and particulate selenium in the San Francisco Bay under altered conditions of river flows and industrial inputs.

\section{Methods}

Study area-The San Francisco Bay is divided into what is known as the Northern Reach and the South Bay. The Northern Reach includes Central Bay, San Pablo Bay, and Suisun Bay (Fig. 2) and is the focus of this modeling effort; the South Bay will not be discussed further. Seawater enters the bay through the Golden Gate and proceeds into the Northern Reach, whereas freshwater from the Sacramento River and the San Joaquin River enters the bay through a complex series of channels, embayments, and marshes known as the "Delta." The Northern Reach has many features in common with other estuaries, namely, short residence time, strong tidal influences, a well to partially mixed water column, and natural and anthropogenic inputs of nutrients and trace elements. Freshwater residence times in the San Francisco Bay range from about 1 week during a high flow period to 3-5 weeks during low flow periods (Cutter 1989).

Model description-The Center for Coastal and Marine Sciences at the Plymouth Marine Laboratory, United Kingdom, developed the biogeochemical model ECoS 3, which can simulate biological productivity, total suspended material, salinity, nutrients, and trace metal behavior in the Tamar estuary. It is commercially available, and therefore only modifications made to the model to simulate the biogeochemical cycle of selenium in the San Francisco Bay (Fig. 1) are discussed. However, Web Appendix 1 (http:// 


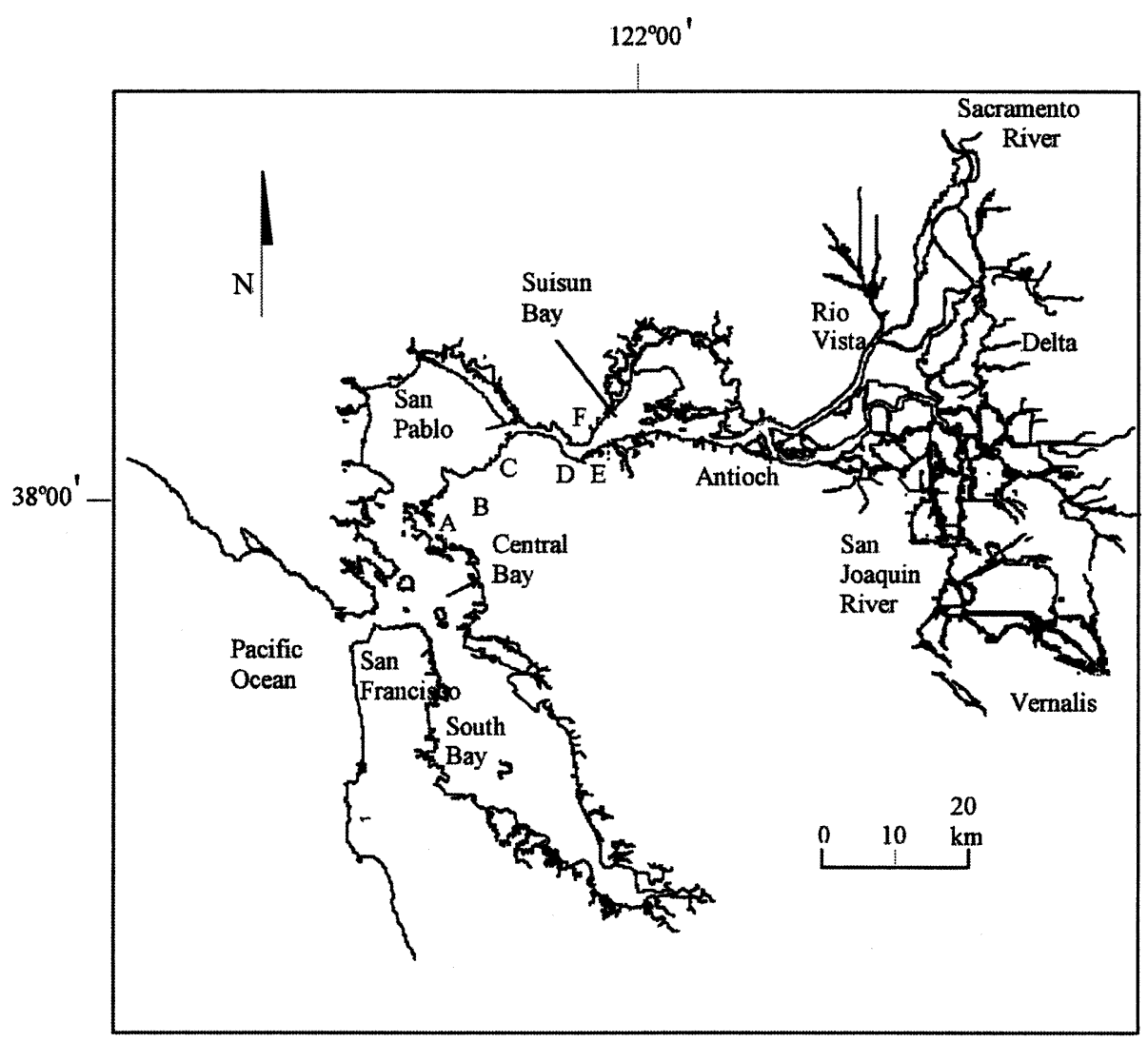

Fig. 2. The San Francisco Bay estuary, with the model domain being from the Golden Gate (between Central Bay and the Pacific Ocean) to Rio Vista on the Sacramento River. Refinery discharges into San Francisco Bay: (Fig. 2 The San Francisco Bay and Sacramento -San Joaquin Delta and the location of six major refineries. A) Chevron USA, Richmond Refinery; (B) Pacific Refining, Hercules; (C) Unocal, Rodeo; (D) Shell Oil, Martinez; (E) Tosco Refining, Martinez; and $(\mathrm{F})$ Exxon USA, Benicia.

www.aslo.org/lo/toc/vol_51/issue_5/2018a1.pdf) has more thorough descriptions of the model and its parameters.

Modeling morphology and hydrology-The San Francisco Bay estuary was modeled as a multibox (33 boxes, each $3.3 \mathrm{~km}$ in length), one-dimensional estuary such that for any solute, s,

$$
\frac{\partial \mathrm{s}}{\partial \mathrm{t}}=\mathrm{u} \frac{\partial \mathrm{s}}{\partial \mathrm{x}}-\frac{\partial}{\partial \mathrm{x}}\left(\mathrm{K}_{\mathrm{x}} \frac{\partial \mathrm{s}}{\partial \mathrm{x}}\right)-\Gamma
$$

where $t$ is time, $u$ is the tidal velocity, $x$ is the axis of the estuary, $\mathrm{K}_{\mathrm{x}}$ is the coefficient of longitudinal eddy diffusion, and $\Gamma$ are other processes/reactions (e.g., biological uptake) that may affect the transport of a constituent (e.g., selenium) and are discussed following. Further information on how the model calculates the movement of a solute from one box to the next is provided in Web Appendix 1.

ECoS 3 has mathematical equations to define the shape of an estuary and its tidal movements (Harris and Gorely 1998), and because these equations were not modified (only the parameters were adjusted for the San Francisco Bay), further discussion on how the model defined the bathymetry and tidal components are given in Web Appendix 1.
Although there are two major river inputs, approximately $98 \%$ of the flow from the San Joaquin River is diverted for irrigation practices, with the lower part of the river dependent on freshwater from agricultural drainage (Presser and Piper 1998). During most of the year, the San Joaquin discharge rate is low, with little or no water entering the estuary. Thus, the Sacramento River largely defined the riverine input of selenium into the Northern Reach and was the single freshwater end member (input) of the model.

However, the elevated dissolved selenium concentrations in the San Joaquin River (Cutter and San Diego-McGlone 1990; Cutter and Cutter 2004) can be an important input of selenium to the estuary when it does flow into the bay. Therefore, the San Joaquin River was treated as a point source (to a specific box) with variable flows over time. Discharge rates for both the Sacramento and San Joaquin rivers were obtained from the Interagency Ecological Program (http://iep.water.ca.gov/dayflow/).

Phytoplankton dynamics-Modeling phytoplankton biomass is difficult because of seasonal variations in community composition and productivity within an estuary but is needed since the biogeochemical cycle of dissolved and 
particulate selenium (Fig. 1) is influenced by biological uptake. In a well mixed estuary, phytoplankton biomass is modeled as

$$
\begin{aligned}
\frac{\partial \mathrm{B}}{\partial \mathrm{t}} & =-\mathrm{U} \frac{\partial \mathrm{B}}{\partial \mathrm{x}}+\mathrm{K}_{\mathrm{x}} \frac{\partial^{2} \mathrm{~B}}{\partial \mathrm{x}^{2}}+\mu_{\mathrm{n}} \mathrm{B}-\mathrm{GB} \\
& -\mathrm{P}_{\mathrm{b}} \mathrm{B}-\frac{\partial}{\partial \mathrm{z}}\left(\mathrm{w}_{\mathrm{s}} \mathrm{B}\right)-\mathrm{RB}+\mathrm{B}_{\text {river }}
\end{aligned}
$$

where $\mathrm{U}$ is the water velocity $\left(\mathrm{m} \mathrm{d}^{-1}\right), \mathrm{B}$ is the phytoplankton biomass (g chlorophyll $\alpha[\mathrm{Chl} a] \mathrm{L}^{-1}$ ), $\mathrm{K}_{\mathrm{x}}$ is the dispersion coefficient along the axis of the estuary $\left(\mathrm{m}^{2} \mathrm{~d}^{-1}\right), \mu_{\mathrm{n}}$ is the net biomass-specific growth rate $\left(\mathrm{d}^{-1}\right)$, $G\left(d^{-1}\right)$ is loss rate attributed to zooplankton grazing, $P_{b}$ $\left(\mathrm{d}^{-1}\right)$ is a loss caused by benthic grazing, $\mathrm{z}$ is the depth $(\mathrm{m}), \mathrm{w}_{\mathrm{s}}$ is the sinking rate $\left(\mathrm{m} \mathrm{d}^{-1}\right), \mathrm{R}\left(\mathrm{d}^{-1}\right)$ is nonspecific natural mortality of phytoplankton caused by anything other than grazing (i.e., respiration), and $\mathrm{B}_{\text {river }}$ is the riverine input of phytoplankton ( $\mathrm{g} \mathrm{Chl} a \mathrm{~L}^{-1} \mathrm{~d}^{-1}$ ). Sinking of phytoplankton tends to be small $\left(0.5-0.9 \mathrm{~m} \mathrm{~d}^{-1}\right)$ and was set to a constant value based on literature values for the San Francisco Bay (Lucas et al. 1998). Mortality caused by respiration can be up to $10 \%$ of the maximum rate of photosynthesis at optimal light intensity $\left(\mathrm{P}_{\mathrm{m}}\right)$ and was held at $10 \%$ of $\mathrm{P}_{\mathrm{m}}$ in this model (Cole and Cloern 1984).

The net biomass-specific growth rate, $\mu_{n}$ in Eq. 2, is calculated as

$$
\mu_{n}=\frac{\mathrm{P}}{\mathrm{C}: \mathrm{Chl}}
$$

where $\mathrm{P}$ is the biomass-specific rate of photosynthesis $(\mathrm{mg}$ $\mathrm{C} \mathrm{mg} \mathrm{Chl} a^{-1} \mathrm{~d}^{-1}$ ), and $\mathrm{C}: \mathrm{Chl}$ is the carbon to Chl $a$ ratio (51 mg C mg Chl $a^{-1}$; Cloern and Alpine 1991) for the bay. The biomass-specific rate of photosynthesis, $\mathrm{P}$, in the San Francisco Bay estuary is light-limited (Cole and Cloern 1984), and thus is determined from the photosynthesisirradiance equation of Platt and Jassby (1976). However, an accurate simulation of the suspended particulate matter is required to accurately reproduce the in situ irradiance. Total suspended material (TSM) in the water column was defined in ECoS 3 (Harris and Gorley 1998), and the settling and resuspension rates were adjusted to those found in the San Francisco Bay. Further details of the parameters used for simulating TSM in the San Francisco Bay are given in Web Appendix 1.

Grazing in the San Francisco Bay includes zooplankton and benthic grazing. The specific loss of phytoplankton per day by zooplankton grazing ( $\mathrm{G}$ in Eq. 2 ) is simulated from Cloern et al. (1985). Benthic grazing of phytoplankton $\left(\mathrm{P}_{\mathrm{b}}\right.$ in Eq. 2) changed largely with the introduction of the invasive clam Potamocorbula amurensis (Werner and Hollibaugh 1993). Before the introduction of P. amurensis, the main control on phytoplankton populations was zooplankton grazing, but the introduction of $P$. amurensis potentially increased phytoplankton grazing rates to values greater than specific growth rates of phytoplankton (Werner and Hollibaugh 1993). Data for the Northern Reach indicate that the largest number of benthic grazers are located in Suisun Bay (Thompson 2000); therefore, benthic grazing rates were increased from $0.04 \mathrm{~d}^{-1}$ to $0.05 \mathrm{~d}^{-1}(25 \%)$ for Suisun Bay.

Dissolved selenium - Results from Cutter and Cutter (2004) were used to parameterize dissolved selenium inputs from the Sacramento and San Joaquin. However, data for the San Joaquin River were taken at Vernalis (Cutter and Cutter 2004), which is approximately $60 \mathrm{~km}$ from where the San Joaquin River enters the Delta. Samples taken in the Delta in 1998 and 2000 (Cutter unpubl. data) indicate that the concentration of selenium may be reduced by $60-80 \%$ as it is being transported from Vernalis through the Delta and into the estuary at Antioch (Fig. 2). Based on this information, a removal constant of $60 \%$, henceforth referred to as the "Delta removal constant," was applied to the input of selenium from the San Joaquin River.

The refineries along the San Francisco Bay have been a major source of selenium input (Cutter and San DiegoMcGlone 1990). The concentration and speciation of selenium from the refineries has varied significantly during the last 10 years (Cutter and Cutter 2004). Refinery inputs of dissolved selenium were treated as point sources in the model, with inputs corresponding to each refinery location identified in Fig. 2. Total selenium output fluxes were obtained from each refinery for the years of interests (San Francisco Bay Regional Water Quality Control Board pers. comm.). Cutter and Cutter (2004) and Cutter and San Diego-McGlone (1990) determined the speciation of selenium from the refinery output, and their data were used in the model.

The in situ processes, $\Gamma$, for modeling dissolved selenium in the bay include production and removal terms (Fig. 1). These processes for selenite, selenate, and organic selenide are described in the model as

$$
\begin{aligned}
\frac{\partial D \mathrm{Se}(\mathrm{IV})}{\partial \mathrm{t}} & =\mathrm{k}_{3}[\mathrm{DSe}(\mathrm{IV})]-\mathrm{k}_{5}[\mathrm{DSe}(\mathrm{VI})] \\
\frac{\partial D \operatorname{Se}(\mathrm{IV})}{\partial \mathrm{t}} & =\mathrm{k}_{2}[\mathrm{DSe}(-\mathrm{II})]-\mathrm{k}_{3}[\mathrm{DSe}(\mathrm{IV})] \\
& -\mathrm{k}_{4}[\mathrm{DSe}(\mathrm{IV})] \\
\frac{\partial D \operatorname{Se}(-\mathrm{II})}{\partial \mathrm{t}} & =\mathrm{k}_{1}[\mathrm{PSe}(-\mathrm{II})]-\mathrm{k}_{2}[\mathrm{DSe}(-\mathrm{II})] \\
& -\mathrm{k}_{6}[\mathrm{DSe}(-\mathrm{II})]
\end{aligned}
$$

Previously determined rate constants (Cutter and Bruland 1984; Cutter 1992) were used for $\mathrm{k}_{1}, \mathrm{k}_{2}$, and $\mathrm{k}_{3}$. The rate constants $\mathrm{k}_{4}, \mathrm{k}_{5}$, and $\mathrm{k}_{6}$ are controlled by phytoplankton (Fig. 1). Typically, Michaelis-Menton uptake kinetics would be used, but few are available for selenium. However, the data that are available (e.g., Vandermeulen and Foda 1988; Riedel et al. 1996) suggest that for the selenium concentrations in the bay, uptake would be in the linear region and thus can be modeled as first-order reactions (see Web Appendix 1). There are many factors affecting dissolved uptake rates, such as the species of phytoplankton that are actually present, but the best available constants were selected for this model. The model 
sensitivity to these rate constant values is described in Web Appendix 2 (http://www.aslo.org/lo/toc/vol_51/issue_5/ 2018a2.pdf). For selenite $\left(\mathrm{k}_{4}\right)$ and selenate $\left(\mathrm{k}_{5}\right)$ the firstorder uptake rate constants from Riedel et al. (1996) were used, since the bay can be dominated by freshwater diatoms in the upper reaches (Lehman 2000). For organic selenide, Baines et al. (2001) found that organic selenide uptake is about half the rate of selenite uptake using phytoplankton species found in the San Francisco Bay. Based on this, the uptake rate constant for organic selenide $\left(\mathrm{k}_{6}\right)$ was set at half of the selenite value.

Pore-water exchange can be a significant source or sink of dissolved selenium to the estuary. Pore-water exchange is modeled as

$$
\frac{\partial \mathrm{Se}_{\text {porewater }}}{\partial \mathrm{t}}=\mathrm{A} \times \mathrm{J}_{\mathrm{Se}}
$$

where $A$ is the area $\left(\mathrm{m}^{2}\right)$ of the sediment, and $\mathrm{J}_{\mathrm{Se}}$ is the diffusive flux $\left(\mathrm{nmol} \mathrm{m}^{-2} \mathrm{yr}^{-1}\right)$. Diffusive fluxes were calculated based on the overlying water selenium concentration (model-generated) and measured pore-water concentrations that vary little with season (Meseck and Cutter unpubl. data).

Particulate selenium - Modeling particulate selenium in the bay requires the ability to model the transport of suspended sediments within the water column as described previously. Particulate selenium in the water column is derived from sediment resuspension, sediment loads from the Sacramento River, and in situ production (e.g., phytoplankton uptake of selenium). This can be expressed as:

$$
\frac{\partial \mathrm{PSe}}{\partial \mathrm{t}}=\mathrm{Se}_{\mathrm{SED}} \frac{\partial \mathrm{BEPS}}{\partial \mathrm{t}}+\mathrm{Se}_{\text {river }} \frac{\partial \mathrm{PSM}}{\partial \mathrm{t}}-\Gamma
$$

where PSe is the particulate selenium concentration $(\mathrm{nmol} \mathrm{L}-1), \mathrm{Se}_{\mathrm{SED}}$ is the selenium concentration in the uppermost sediment that can be resuspended ( $\mathrm{nmol} \mathrm{g}^{-1}$; Meseck and Cutter unpubl. data), BEPS is the load of resuspended sediment $\left(\mathrm{g} \mathrm{L}^{-1}\right.$ generated in the model through tidal movement and river flows), $\mathrm{Se}_{\text {river }}$ is the concentration of selenium in riverine particles $\left(\mathrm{nmol} \mathrm{g}^{-1}\right.$; Doblin et al. 2006), PSM is permanently suspended material in the river $\left(\mathrm{g} \mathrm{L}^{-1}\right)$, and $\Gamma$ is all the in situ reactions/processes, which will be defined below for each species of particulate selenium.

With respect to the speciation of particulate selenium and in situ processes, elemental selenium is primarily generated by dissimilatory selenite + selenate reduction (Oremland et al. 1989; Cutter 1992). Since the water column of San Francisco Bay is oxic, the presence of particulate elemental selenium in total suspended material can be attributed to either sediment resuspension or riverine particulate inputs (i.e., $\Gamma=0$ ). For particulate selenite + selenate, besides sediment inputs, in situ adsorption/desorption processes can affect this concentration in the water column. The in situ adsorption/desorption of selenite + selenate was modeled by the distribution coefficient $K_{d}=a^{\prime} / b$, where $a^{\prime}$ is the intrinsic adsorption rate constant $\left(\mathrm{L} \mathrm{g}^{-1} \mathrm{~d}^{-1}\right)$, and $\mathrm{b}$ is the rate constant $\left(\mathrm{d}^{-1}\right)$ of desorption (Nyffeler et al. 1984). The value of $K_{d}$ was obtained from Zhang and Moore (1996), and values of a' were obtained from Nyffeler et al. (1984). The rate constant $\mathrm{b}$ was obtained by rearranging the $\mathrm{K}_{\mathrm{d}}$ equation to $\mathrm{b}=a^{\prime}$ / $\mathrm{K}_{\mathrm{d}}$. Similarly, sediment inputs and in situ processes control the concentration of particulate organic selenide. Once phytoplankton take up dissolved selenium, it is converted into particulate organic selenide as controlled by $\mathrm{k}_{4}, \mathrm{k}_{5}$, and $\mathrm{k}_{6}$ (Eqs. 4-6).

\section{Results}

Model validation - Sensitivity analyses of the model are discussed in Web Appendix 2, and only the validation results are presented here to illustrate its performance. Three statistical tests were used to determine the ability of the model to reproduce observed behaviors of the various modeled parameters. They included the linear correlation coefficient, the mean cumulative error $(M$, the bias of the model), and the confidence interval (CI). For the linear correlation coefficient, the $95 \% \mathrm{CI}$ was used $(p<0.05)$. The mean cumulative error indicates if the model was underpredicting relative to the observed values (a negative value) or overpredicting (a positive sign). The confidence interval is not affected by outliers or data variation because it measures the absolute difference between the predicted concentrations of the model and the actual data and is probably one of the better measures of model performance (Perrin et al. 2001).

Estuarine profiles of salinity, phytoplankton biomass, total suspended material, and dissolved and particulate selenium from 1986 and 1998 were used for validation (1999 data were used for calibration) because they represent extremes in several parameters, including river discharge and an increase in benthic grazing from the invasive clam P. amurensis. Furthermore, these years represent periods of low (38 mol Se d $\left.{ }^{-1}, 1998\right)$ and high (99 $\left.\mathrm{mol} \mathrm{Se} \mathrm{d}^{-1}, 1986\right)$ refinery discharge of total dissolved selenium, and the speciation in their effluents changed from primarily selenite in 1986 to selenate in 1998 (Cutter and San DiegoMcGlone 1990; Cutter and Cutter 2004). The 1986 and 1998 data sets also have data available during high flow months (April 1986, June 1998) and low flow months (September 1986, October 1998), providing a variety of conditions within the estuary to validate the model.

Salinity, TSM, and phytoplankton-The model must be able to simulate the physical transport in an estuary (i.e., salinity), phytoplankton growth, and TSM, because these are critical parts of the biogeochemical cycle of selenium (Fig. 1). The model was able to reproduce the observed salinity profiles at $r$ values $>0.95$ (Table 1 ) for the observed salinities in 1986 and 1998 (Fig. 3). More specifically, the model underpredicted salinity (-0.07) for 23 April 1986 and overpredicted it for 23 September 1986, 12 June 1998, and 12 October 1998 (Table 1). The confidence intervals of the model to simulate salinities ranged from $80 \%$ to $97 \%$ (Table 1). Overall, Fig. 3 and the $r$, CI, and $M$ results show that the model was able to accurately reproduce the salinity 
Table 1. Summary of validation results for various years for salinity, phytoplankton biomass, and total suspended material. The table gives the linear correlation $(r)$, mean cumulative error $(M)$, and confidence interval $(\mathrm{CI})$ between the observed data and model simulations.*

\begin{tabular}{|c|c|c|c|c|c|c|c|c|c|}
\hline Year & \multicolumn{3}{|c|}{ Salinity } & \multicolumn{3}{|c|}{ Phytoplankton } & \multicolumn{3}{|c|}{ TSM } \\
\hline 23 Apr 1986 & $0.966 t$ & -0.07 & 92 & $0.789+$ & +0.97 & 84 & $0.678 \%$ & +2.8 & 93 \\
\hline 08 Oct 1987 & $0.979 \ddagger$ & -0.08 & 96 & NA & NA & NA & NA & NA & NA \\
\hline 15 Mar 1988 & $0.952 \ddagger$ & -0.27 & 80 & NA & NA & NA & NA & NA & NA \\
\hline 11 May 1988 & $0.979 \div$ & +0.35 & 97 & NA & NA & NA & NA & NA & NA \\
\hline 12 Oct 1998 & $0.960 \ddagger$ & +0.08 & 86 & $0.561+$ & +0.41 & 78 & 0.879 & -1.3 & 96 \\
\hline
\end{tabular}

* NA, data not available.

$\dagger-$, model was underpredicting relative to the observed; + , model was overpredicting.

\$ Linear correlation was significant at $p<0.05$.

profiles for the various conditions in 1986 and 1998. As a result, all remaining figures were plotted against salinity so that removal/production processes can be observed (e.g., as in Cutter and Cutter 2004).

Particulate selenium profiles in the estuary are affected by processes controlling total suspended material, making it essential that the model reproduce the estuarine profiles of TSM. Model-generated simulations show maxima in the upper reaches of the estuary that agree with the observed data in 1986 and 1998 (Fig. 3), and the high linear correlation coefficients, high CI, and low $M$ (Table 1) indicate that the model validation for TSM was fully acceptable. Nevertheless, it should be noted that the model does not simulate wind mixing, so these events will not be included in the simulations (but also do not appear to be important for these validation periods as the model captures most of the observed behaviors).

The uptake of dissolved selenium and the production of particulate organic selenide are largely a function of phytoplankton biomass, and therefore accurate model reproductions of the observed phytoplankton distributions are required. Model simulations of phytoplankton biomass were similar to the observed data for 1986 and 1998 (Fig. 3), although the model did overpredict phytoplankton biomass in both years (from $0.41 \mu \mathrm{g} \mathrm{Chl} a \mathrm{~L}^{-1}$ to $0.97 \mu \mathrm{g}$ $\mathrm{Chl} a \mathrm{~L}^{-1}$; Table 1). The linear correlation was significant $(p<0.05)$ for all the months simulated except for 12 June 1998 (Table 1). Model-generated phytoplankton biomass in June was overpredicted for the entire estuary, and sensitivity analyses of the model (Web Appendix 2) indicate that phytoplankton biomass was largely controlled by grazing. Therefore, it is possible that for June 1998, grazing of phytoplankton biomass was slightly underestimated. However, even though the linear correlation was not significant, the model was still able to predict $75 \%$ of the observed data (Table 1). Other than this month, the simulation results show that the model is accurately predicting phytoplankton biomass (Table 1). Significantly, the validation periods included an extreme change in benthic grazing rates, and the model confirmed the empirical observations of lowered phytoplankton biomass in the estuary because of this change (Cloern and Alpine 1991).

Dissolved selenium, high flow months-For 1986, high flow samples were taken in April, whereas in 1998 they were taken in June. Total dissolved selenium in the estuary displayed conservative mixing behavior in April 1986 (Fig. 4A) and appears nonconservative in June 1998 (Fig. 4B). Model simulations reproduced the conservative and nonconservative behavior of total dissolved selenium for both months ( $r, \mathrm{CI}$, and $M$ in Table 2).

Selenite concentrations in the estuary ranged from $0.2 \mathrm{nmol} \mathrm{L}^{-1}$ to $0.6 \mathrm{nmol} \mathrm{L}^{-1}$ and showed nonconservative behavior (Fig. 4C,D) that the model was able to reproduce for both months. On 23 April 1986, the confidence of the model was $95 \%$, it slightly underpredicted selenite $\left(-0.02 \mathrm{nmol} \mathrm{L}^{-1}\right)$, and the correlation coefficient was significant $(r=0.902)$. For 12 June 1998, the correlation coefficient was not significant $(r=0.435)$, but the confidence interval was $99 \%$ and the mean cumulative error was $0.00 \mathrm{nmol} \mathrm{L}^{-1}$, indicating that there was an excellent fit between the observed and modeled concentrations (Table 2).

Observed selenate concentrations varied from $1.0 \mathrm{nmol}$ $\mathrm{L}^{-1}$ to a maximum of $2.0 \mathrm{nmol} \mathrm{L}^{-1}$ (Fig. 4E,F), with selenate displaying nonconservative behavior in April 1986 (Fig. 4E) and conservative in June 1998 (Fig. 4F). Simulated estuarine profiles reproduced these behaviors, with a 76\% confidence on April 1986 and a 75\% confidence in June 1998 (Table 2). The linear correlation coefficient was significant for April $(r=0.832)$ and June $(r=0.574)$, with a cumulative error of $-0.25 \mathrm{nmol} \mathrm{L}^{-1}$ for 23 April 1986 and $+0.38 \mathrm{nmol} \mathrm{L}^{-1}$ for 12 June 1998 (Table 2).

Dissolved organic selenide concentrations varied from nondetectable to approximately $2.0 \mathrm{nmol} \mathrm{L}-1$ for the months examined and displayed nonconservative behavior in the estuary (Fig. 4G,H). The correlation coefficient for 23 April 1986 was not significant $(r=0.319)$, but the high confidence interval (92\%) and low mean cumulative error $\left(-0.05 \mathrm{nmol} \mathrm{L}^{-1}\right.$; Table 2) indicate that the model was able to reproduce the observed dissolved organic selenide 

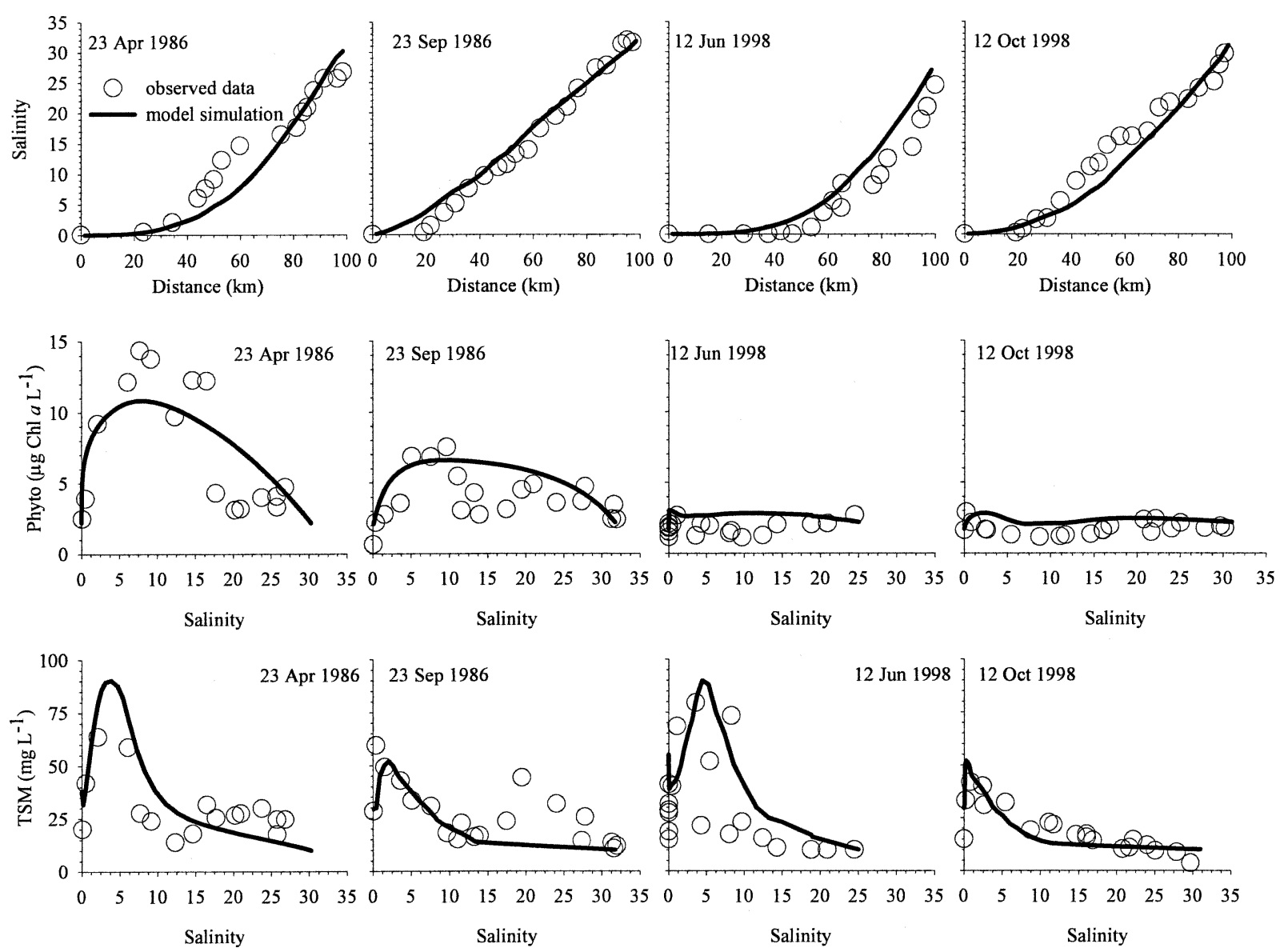

Fig. 3. Estuarine profiles of model-generated and observed salinity, TSM, and phytoplankton biomass (as Chl $a$ ) for 1986 and 1998 in the San Francisco Bay.

profile. For the high flow month of 12 June 1998, the model was able to predict $80 \%$ of the dissolved organic selenide in the estuary (Table 2).

Dissolved selenium, low flow months-Samples taken on 23 September 1986 and 12 October 1998 for dissolved selenium represent the low river flow months in the San Francisco Bay. Observed total dissolved selenium during these periods displayed nonconservative behavior within the estuary, although the concentration in 1986 reached a maximum of $4 \mathrm{nmol} \mathrm{L}^{-1}$, whereas in 1998 the maximum was only $2.0 \mathrm{nmol} \mathrm{L}^{-1}$. Model simulations were able to reproduce these nonconservative behaviors (Fig. 5A,B) for both years ( $r, \mathrm{CI}$, and $M$ values in Table 2).

Selenite concentrations on 23 September 1986 reached a mid-estuary maximum of $1 \mathrm{nmol} \mathrm{L}-1$ (Fig. 5C), whereas on 12 October 1998 the mid-estuary maximum was only $0.5 \mathrm{nmol} \mathrm{L}^{-1}$ (Fig. 5D) because of decreased selenite fluxes from refineries (Cutter and Cutter 2004). For September 1986 the model underpredicted selenite $(-0.13 \mathrm{nmol} \mathrm{L}-1)$, but the correlation coefficient was significant $(r=0.946)$ and was able to reproduce $85 \%$ of the observed data (Table 2). The fit for October 1998 was just as good, with a confidence of $81 \%$, a mean cumulative error of $-0.06 \mathrm{nmol} \mathrm{L}^{-1}$, and a significant correlation coefficient $(r=0.688)$.
Estuarine concentrations in 1986 and 1998 for selenate were similar and ranged from $0.2 \mathrm{nmol} \mathrm{L}^{-1}$ to $1.2 \mathrm{nmol} \mathrm{L}^{-1}$ (Fig. 5E,F). The correlation coefficient for 23 September 1986 was not significant $(r=0.296)$, but the model reproduced the observed estuarine profile of selenate at a confidence interval of $91 \%$ and slightly underpredicted selenate $\left(-0.06 \mathrm{nmol} \mathrm{L}^{-1}\right.$; Table 2). For 12 October 1998 , the correlation coefficient was significant $(r=0.589)$, and although the model underpredicted selenate $(-0.19 \mathrm{nmol}$ $\mathrm{L}^{-1}$ ), it was still able to simulate $77 \%$ of the observed selenate behavior (Table 2).

The estuarine profiles for organic selenide in the low flow months display nonconservative profiles within the estuary (Fig. 5G,H). Model simulations of organic selenide reproduced the observed estuarine profiles at a 96\% confidence interval in 23 September 1986 and $63 \%$ in October 1998 (Table 2). For both years the linear correlations were significant, but for the 23 September 1986 simulation the model slightly underpredicted organic selenide $\left(-0.02 \mathrm{nmol} \mathrm{L}^{-1}\right)$ and overpredicted organic selenide on 12 October 1998 (+0.13 nmol $\mathrm{L}^{-1}$; Table 2).

Table 2 summarizes the $r$, CI, and $M$ values for all the dissolved selenium data that were available for validating the model. The confidence interval of the model varied 

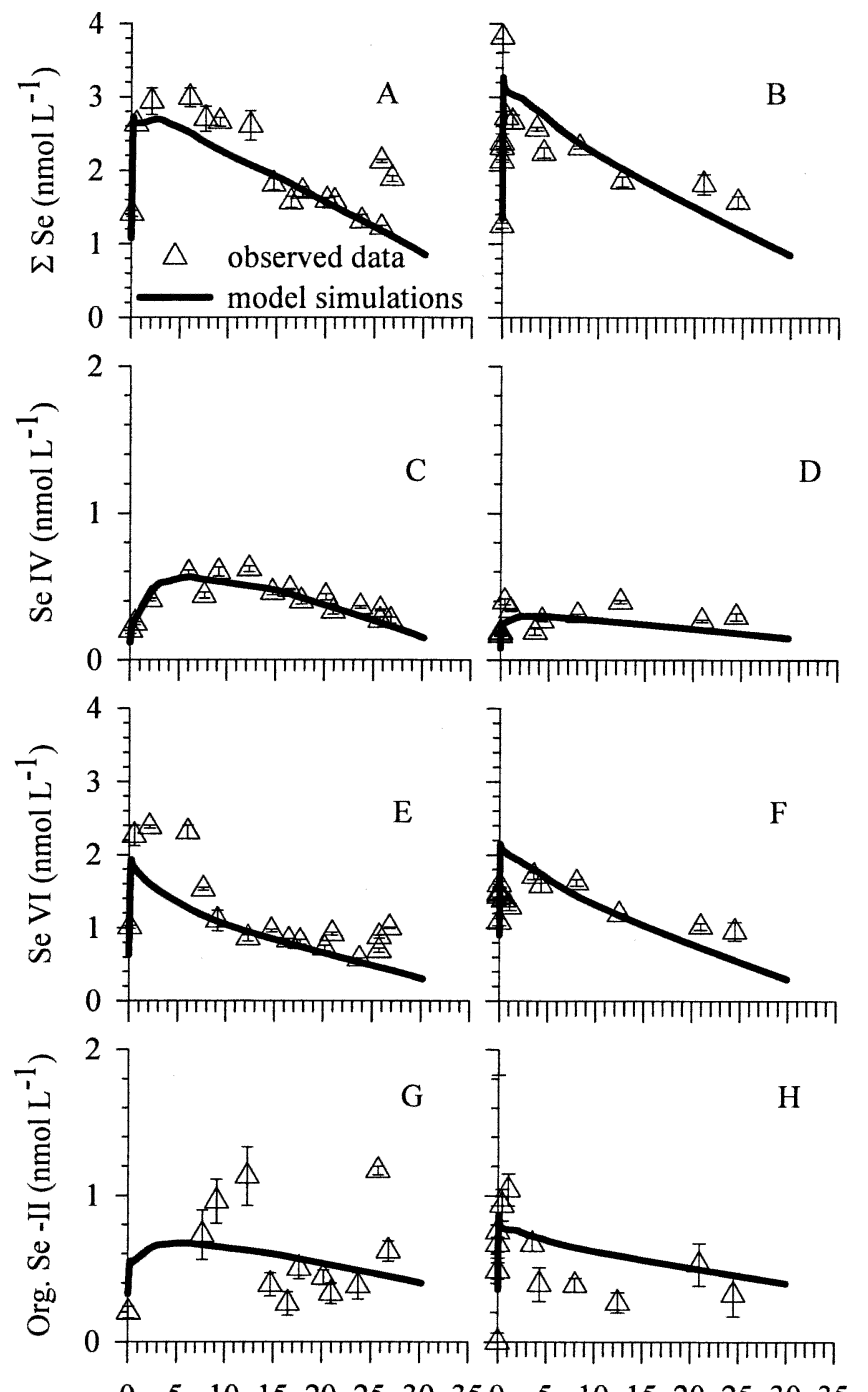

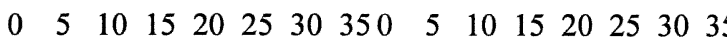

Salinity

Salinity

Fig. 4. High flow model-generated (A) total dissolved selenium, (C) selenite, (E) selenate, and (G) organic selenide and observed data for 23 April 1986 and (B) total dissolved selenium, (D) selenite, (F) selenate, and (H) organic selenide and observed data for 12 June 1998.

from a low of $60 \%$ to a high of $99 \%$ of the observed behavior (Table 2). Furthermore, most of the correlation coefficients were significant, and for those that were not, there was usually a low mean cumulative error (e.g., $0.00 \mathrm{nmol} \mathrm{L}^{-1}$ for selenite on 12 June 1998) and a high model confidence interval (Table 2). Overall, the model performance for simulating the behavior of dissolved selenium under extremely variable environmental conditions is very good.

Particulate selenium - For both high (12 June 1998) and low flows (12 October 1998), total particulate selenium concentrations ranged from $0.1 \mathrm{nmol} \mathrm{L}^{-1}$ to $0.3 \mathrm{nmol} \mathrm{L}-1$ (Fig. 6A,B), with higher concentrations located near the maxima of total suspended material (Fig. 3). Model-
Table 2. Model validation results for dissolved selenium and its speciation in the San Francisco Bay. The linear correlation $(r)$, mean cumulative error $(M)$, and confidence interval (CI) between the observed data and model simulations are given.

\begin{tabular}{|c|c|c|c|}
\hline Year & $r$ & $M^{*}(\mathrm{nmol} \mathrm{L}-1)$ & $\mathrm{CI}(\%)$ \\
\hline \multicolumn{4}{|l|}{23 Apr 1986} \\
\hline Total selenium & $0.791 \dagger$ & -0.18 & 91 \\
\hline Selenite & $0.902 \dagger$ & -0.02 & 95 \\
\hline Selenate & $0.832 \dagger$ & -0.25 & 76 \\
\hline Organic selenide & 0.319 & -0.05 & 92 \\
\hline \multicolumn{4}{|l|}{23 Sep 1986} \\
\hline Total selenium & $0.882 \dagger$ & -0.16 & 92 \\
\hline Selenite & $0.946 \dagger$ & -0.13 & 85 \\
\hline Selenate & 0.296 & -0.06 & 91 \\
\hline Organic selenide & $0.576 \dagger$ & -0.02 & 96 \\
\hline \multicolumn{4}{|l|}{08 Oct 1987} \\
\hline Total selenium & $0.568 \dagger$ & -0.12 & 96 \\
\hline Selenite & $0.543 \dagger$ & +0.06 & 95 \\
\hline Selenate & $0.561 \dagger$ & -0.35 & 72 \\
\hline Organic selenide & 0.111 & +0.01 & 98 \\
\hline \multicolumn{4}{|l|}{15 Mar 1988} \\
\hline Total selenium & $0.991 \dagger$ & +0.03 & 99 \\
\hline Selenite & $0.890 \dagger$ & +0.01 & 98 \\
\hline Selenate & $0.497 \dagger$ & -0.10 & 90 \\
\hline Organic Selenide & 0.625 & +0.09 & 80 \\
\hline \multicolumn{4}{|l|}{11 May 1988} \\
\hline Total selenium & $0.589 \dagger$ & +0.06 & 97 \\
\hline Selenite & $0.807 \dagger$ & -0.11 & 89 \\
\hline Selenate & 0.197 & -0.13 & 87 \\
\hline Organic Selenide & 0.110 & +0.11 & 76 \\
\hline \multicolumn{4}{|l|}{06 Nov 1997} \\
\hline Total selenium & $0.550 \dagger$ & -0.22 & 91 \\
\hline Selenite & $0.551 \dagger$ & -0.08 & 87 \\
\hline Selenate & $0.622 \dagger$ & -0.48 & 63 \\
\hline Organic selenide & $0.525 \dagger$ & +0.25 & 60 \\
\hline \multicolumn{4}{|l|}{12 Jun 1998} \\
\hline Total selenium & 0.445 & +0.06 & 96 \\
\hline Selenite & 0.435 & 0.00 & 99 \\
\hline Selenate & $0.574 \dagger$ & +0.38 & 75 \\
\hline Organic selenide & 0.532 & +0.03 & 80 \\
\hline \multicolumn{4}{|l|}{12 Oct 1998} \\
\hline Total selenium & $0.613 \dagger$ & -0.11 & 93 \\
\hline Selenite & $0.688 \dagger$ & -0.06 & 81 \\
\hline Selenate & $0.589 \dagger$ & -0.19 & 77 \\
\hline Organic selenide & $0.607 \dagger$ & +0.13 & 63 \\
\hline
\end{tabular}

* - , model underpredicted; + , the model overpredicted.

$\dagger$ Linear correlation is significant at $p<0.05$.

derived total particulate selenium concentrations reproduced the observed upper estuarine maxima (Fig. 6A,B) for both years ( $r$, CI, and $M$ results in Table 3 ).

Unlike dissolved selenium, speciation data for particulate selenium for high and low flow months were only available in 1998 (Doblin et al. 2006). There was little variation in the estuarine profiles of particulate selenite + selenate (Fig. 6C,D) for both June and October, with the concentrations ranging from nondetectable to 

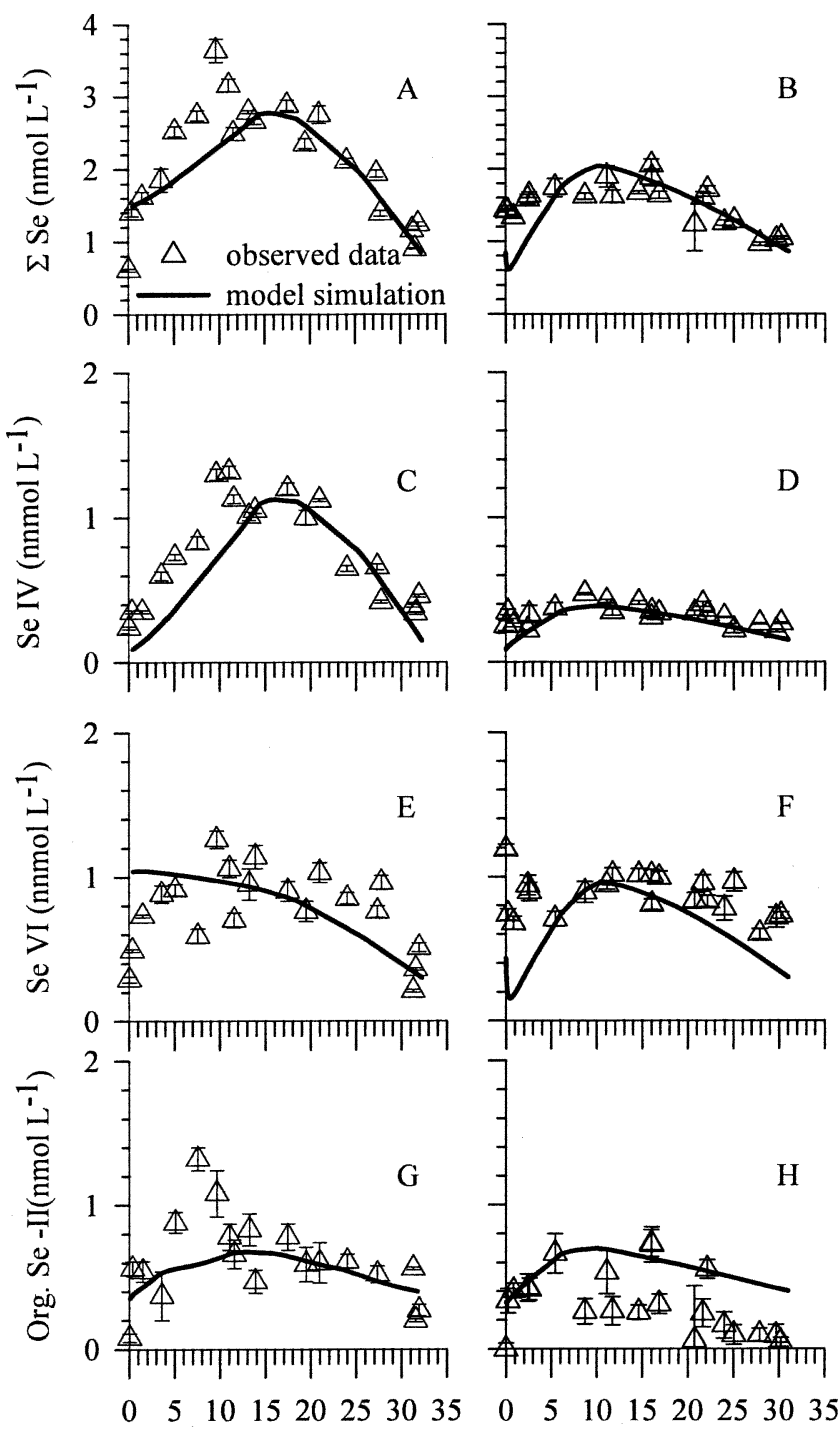

Salinity
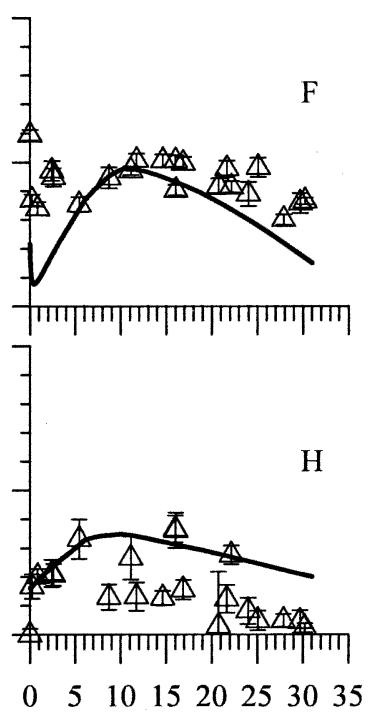

Salinity

Fig. 5. Low flow model-generated (A) total dissolved selenium, (C) selenite, (E) selenate, and (G) organic selenide and observed data for 23 September 1986 and (B) total dissolved selenium, (D) selenite, $(\mathrm{F})$ selenate, and $(\mathrm{H})$ organic selenide and observed data for 12 October 1998.

$0.15 \mathrm{nmol} \mathrm{L}{ }^{-1}$. Simulated particulate selenite + selenate concentrations are within the errors of the observed data (Fig. 6C,D). The linear correlations were insignificant for June and October 1998 simulations; however, the confidence interval in June 1998 was $80 \%$ and $77 \%$ in October 1998 , and the model slightly overpredicted particulate selenite + selenate in October $\left(+0.01 \mathrm{nmol} \mathrm{L}^{-1}\right)$, and slightly underpredicted the concentrations in June $\left(-0.02 \mathrm{nmol} \mathrm{L}^{-1}\right.$; Table 3). Differences between the observed and simulated data may be caused by difficulties in quantifying adsorption/desorption in the model. For example, absorption/desorption studies of selenite + selenate were done in freshwater (Zhang and Moore 1996) and may not be applicable to an estuarine environment.

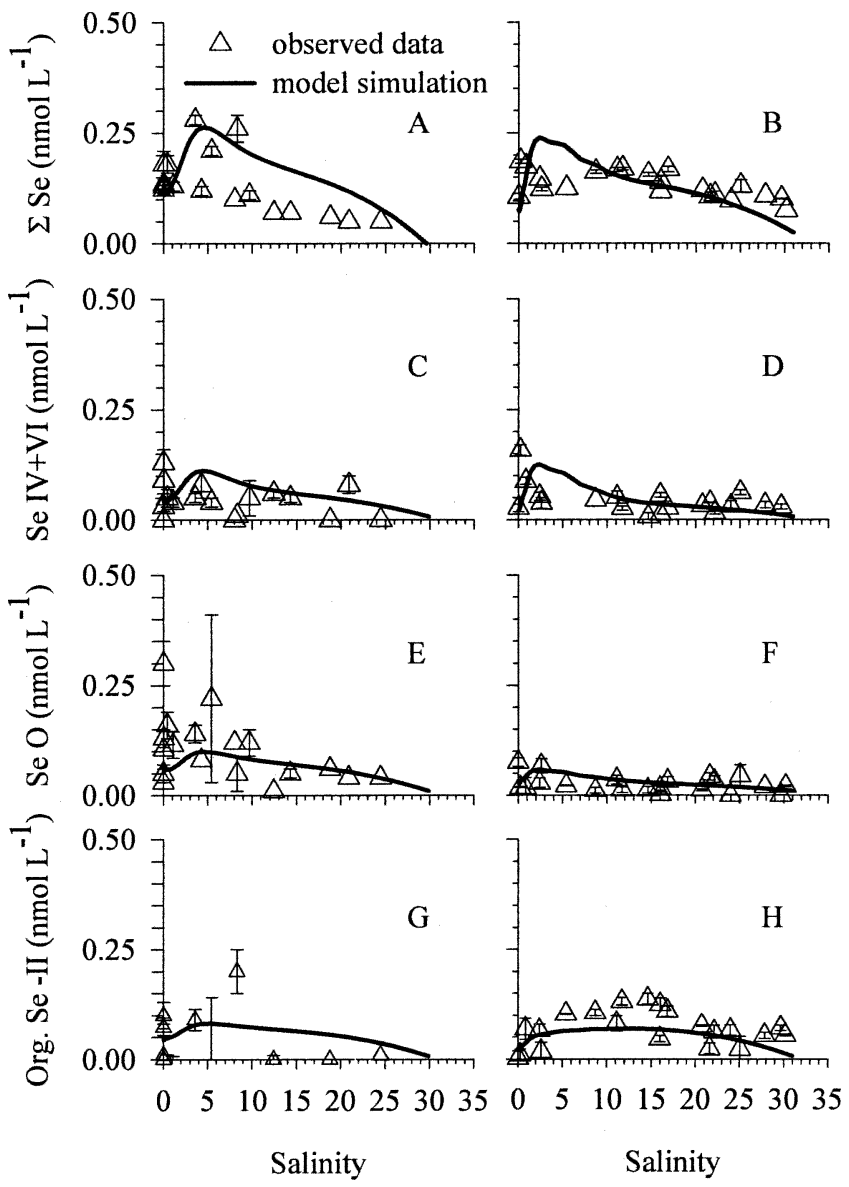

Fig. 6. Model-generated (A) total particulate selenium, (C) selenite, (E) selenate, and (G) organic selenide and observed data for 12 June 1998 and model-generated (B) total particulate selenium, (D) selenite, $(\mathrm{F})$ selenate, and $(\mathrm{H})$ organic selenide and observed data for 12 October 1998.

Sensitivity analyses of adsorption/desorption process indicate that adsorption/desorption coefficients may significantly affect predictions of estuarine particulate selenite + selenate (Web Appendix 2). Further studies of the adsorption/desorption of selenite + selenate on estuarine particles are certainly needed.

Observed particulate elemental selenium concentrations ranged from nondetectable to $0.25 \mathrm{nmol} \mathrm{L}^{-1}$ (Fig. 6E,F), with higher concentrations located in the upper estuary. Model-derived concentrations of elemental selenium produced an estuarine distribution similar to the observed data for both June 1998 and October 1998 (Fig. 6E,F, respectively). The linear correlation for both months was not significant, but the confidence interval was $80 \%$ in June and $98 \%$ in October (Table 3 ). The model slightly overpredicted elemental selenium in June $(0.01 \mathrm{nmol} \mathrm{L}-1)$, but agreed perfectly for October $\left(0.00 \mathrm{nmol} \mathrm{L}^{-1}\right.$; Table 3$)$.

Doblin et al. (2006) found that in October 1998 there was a mid-estuary maximum of particulate organic selenide (Fig. 6H), whereas in June most of the observed concentrations were below the detection limits (Fig. 6G). As with dissolved organic selenide, particulate organic selenide is 
Table 3. Model validation of particulate selenium and its speciation for San Francisco Bay. The linear correlation $(r)$, mean cumulative error $(M)$, and confidence interval (CI) between the observed data and model simulations are given.

\begin{tabular}{lccc}
\hline \hline & $r$ & $M^{*}(\mathrm{nmol} \mathrm{L}-1)$ & CI $(\%)$ \\
\hline 23 Apr 1986 & & \\
Total selenium & $0.742 \dagger$ & +0.01 & 93 \\
23 Sep 1986 & & \\
Total selenium & $0.778 \dagger$ & +0.03 & 84 \\
06 Nov 1997 & & & \\
Total selenium & $0.439 \dagger$ & +0.02 & 85 \\
Selenite + selenate & $0.683 \dagger$ & -0.01 & 82 \\
Elemental & -0.261 & -0.01 & 87 \\
Organic selenide & -0.115 & -0.01 & 83 \\
12 Jun 1998 & & & \\
Total selenium & $0.425 \dagger$ & +0.03 & 76 \\
Selenite + selenate & 0.185 & -0.02 & 80 \\
Elemental & -0.288 & +0.01 & 80 \\
Organic selenide & 0.211 & -0.02 & 70 \\
12 Oct 1998 & & & \\
Total selenium & $0.623 \dagger$ & -0.03 & 78 \\
Selenite + selenate & 0.152 & +0.01 & 77 \\
Elemental & 0.124 & 0.00 & 98 \\
Organic selenide & $0.446 \dagger$ & -0.01 & 77 \\
\hline
\end{tabular}

* -, model underpredicted relative to the observed; +, the model overpredicted.

$\dagger$ Linear correlation is significant at $p<0.05$.

determined by difference [ $\Sigma \mathrm{PartSe}-\mathrm{Se}(0)-\mathrm{Se}(\mathrm{IV}+\mathrm{VI})]$ and often results in larger error bars in the observed data (Fig. 6G,H). Model simulations were able to reproduce the observed behavior by 70\% in June 1998 and $77 \%$ in October 1998 (Table 3). For all simulations of particulate organic selenide, the model underpredicted the amount of organic selenide relative to the observed data (Table 3). Sensitivity analyses (Web Appendix 2) showed that phytoplankton uptake constants $\left(\mathrm{k}_{4}, \mathrm{k}_{5}, \mathrm{k}_{6}\right)$ are important variables for simulating particulate organic selenide, but as noted above, are poorly constrained for phytoplankton in the San Francisco Bay (uptake may be even higher than that used in the model). By improving these rate constants, the ability to predict particulate organic selenide should improve, although with the currently available data the model can simulate at least $70 \%$ of the observed behavior.

Overall, the model reproduced the majority of selenium's estuarine behavior under extreme changes in river and refinery inputs and in the ecosystem structure (changing from pelagic- to benthic-dominated grazing). However, it also provides insights into the biogeochemical cycle of selenium in the San Francisco Bay estuary that were not readily apparent or studied. On a simplistic level, discrepancies between model simulations and observed data are the result of either the model not including important processes or the observations being insufficient (e.g., sampling density or timing) to reveal other processes. An excellent example of a model-derived insight is the
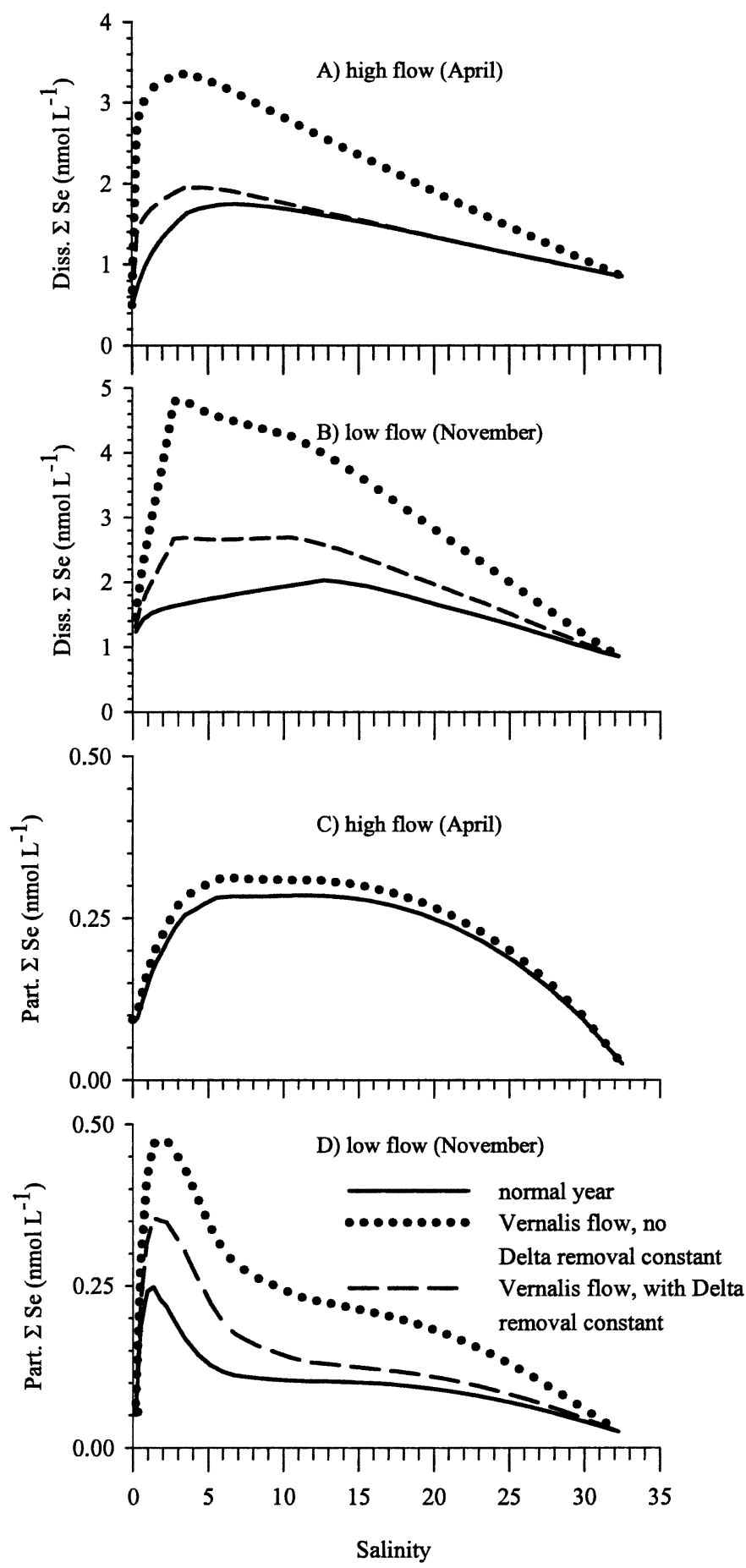

Fig. 7. (A) Model predictions for total dissolved selenium during a high flow month and (B) a low flow month and (C) total particulate selenium for a low flow month and (D) a high flow month in the San Francisco Bay under varying flows from the San Joaquin River. The "normal year" simulation used the Vernalis flow minus Delta withdrawals and imposed a Delta removal constant of $60 \%$ for all selenium inputs. "Vernalis flow, no Delta removal constant" simulations used the full flow at Vernalis without any withdrawals and no $60 \%$ selenium removal. "Vernalis flow, with Delta removal constant" simulations used the full flow at Vernalis without any withdrawals, but used the $60 \%$ selenium removal constant in the Delta. 
Table 4. Predicted particle-associated selenium concentrations (as averages for the entire estuary) during a typical high flow (April) and low flow month (November) for different river discharge from the San Joaquin River and different refinery inputs.

\begin{tabular}{lc}
\hline \hline & $\begin{array}{c}\text { Particulate } \Sigma \text { Se } \\
\left(\mu \mathrm{g} \mathrm{g}^{-1}\right)\end{array}$ \\
\hline April & \\
$\quad$ Vernalis flow, no Delta removal constant & $0.44 \pm 0.28$ \\
$\quad$ Vernalis flow, with Delta removal & $0.44 \pm 0.26$ \\
$\quad$ constant & $0.43 \pm 0.26$ \\
$\quad$ Normal San Joaquin flow & \\
November & $1.00 \pm 0.32$ \\
$\quad$ Vernalis flow, no Delta removal constant & $0.64 \pm 0.16$ \\
$\quad$ Vernalis flow, with Delta removal & \\
constant & $0.51 \pm 0.11$ \\
Normal San Joaquin flow & \\
April & $0.43 \pm 0.26$ \\
99 mol d $^{-1}$ total selenium & $0.43 \pm 0.26$ \\
38 mol d & \\
No refinery inputs & $0.43 \pm 0.26$ \\
November & \\
99 mol d $^{-1}$ total selenium & $0.62 \pm 0.14$ \\
38 mol d & \\
No refinery inputs & $0.51 \pm 0.11$ \\
\end{tabular}

importance of selenite and selenite adsorption/desorption onto particles. Without adsorption/desorption in the model, particulate selenite + selenate were underpredicted, and a $25 \%$ variation in the adsorption/desorption constant resulted in a $50 \%$ change in the particulate selenite + selenate within the estuary during low flow months. Relevant adsorption constants are not available for selenium in an estuarine environment, and the results of the model argue that they should be obtained. Another powerful use of such a model is assessing the relative importance of processes or inputs. For the San Francisco Bay the sources of suspended particulate selenium (in situ, riverine, sediment resuspension) are critically important as this phase is what is consumed by grazers and made available to the estuarine food web (e.g., Stewart et al. 2004; Luoma and Rainbow 2005). In this respect, the model results and sensitivity analyses found that during high flow months particles within the estuary are primarily controlled by riverine inputs; during low flow months, in situ processes account for most of the variation in particulate selenium within the estuary. For example, during a low flow month, varying the river discharge by $25 \%$ resulted in only a $22 \%$ change in particulate organic selenide within the estuary, whereas varying phytoplankton productivity by only $25 \%$ resulted in a $157 \%$ change. By dividing the observed total particulate selenium $\left(\mathrm{nmol} \mathrm{L}^{-1}\right)$ by the total suspended material concentration $\left(\mathrm{mg} \mathrm{L}^{-1}\right)$ the particle-associated selenium $\left(\mu \mathrm{g} \mathrm{g}^{-1}\right)$ can be calculated. We find that during high flow (23 April 1986) the particleassociated selenium is $0.41 \pm 0.07 \mu \mathrm{g} \mathrm{g}^{-1}$, which is almost

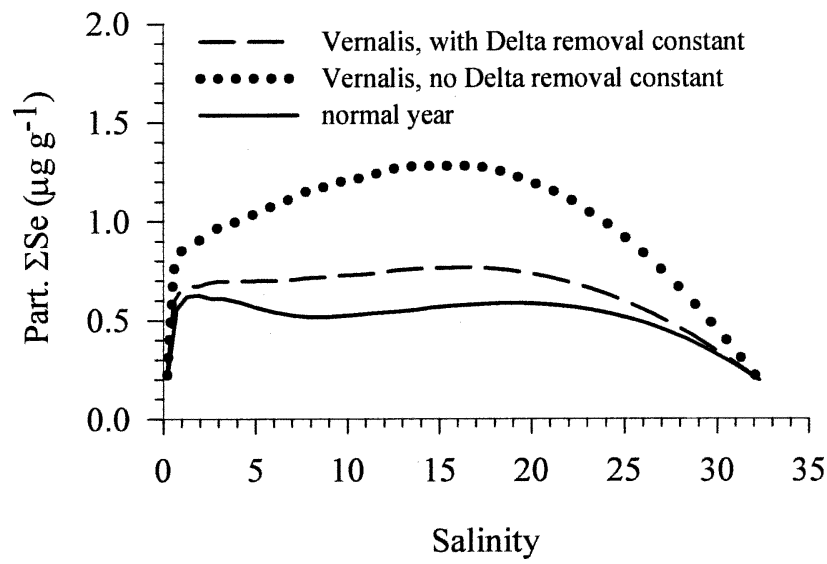

Fig. 8. Model predictions of particle-associated selenium in the San Francisco Bay for three different San Joaquin flow scenarios. The "normal flow" simulation used the Vernalis flow minus Delta withdrawals and imposed a Delta removal constant of $60 \%$ for all selenium inputs. "Vernalis flow, no Delta removal constant" used the full flow at Vernalis without any withdrawals and no $60 \%$ selenium removal; "Vernalis flow, with Delta removal constant" used the full flow at Vernalis without any withdrawals, but used the $60 \%$ selenium removal constant in the Delta.

two times lower than at low flow $\left(0.74 \pm 0.24 \mu \mathrm{g} \mathrm{g}^{-1}\right.$; 23 September 1986). These empirical results confirm the conclusions drawn from model-derived "observations" (i.e., sensitivity analyses). Simulation models can also be used in a predictive or forecasting mode, and this application is discussed next.

Predictive modeling-Having shown that the model was able to accurately simulate the observed behavior of dissolved and particulate selenium under a variety of environmental conditions, it can be used for predictive purposes. Because the behavior of selenium in the San Francisco Bay is largely controlled by river flow and refinery inputs (Cutter and Cutter 2004), two scenarios were examined: higher San Joaquin River flow and higher refinery discharges. For brevity, only the predicted total dissolved and particulate selenium results are discussed in this article.

Increasing San Joaquin River discharge-The State of California has a goal to "reduce the impacts of water diversion on the Bay-Delta system" and thus increase the discharge from the San Joaquin River into the bay (see http://www.baydeltawatershed.org/pdf/prog_plan.pdf). To evaluate the potential effects of increasing the San Joaquin River discharge, simulations were done using the full discharge of water at Vernalis (the freshwater end member of the San Joaquin, before the water is diverted for irrigation practices) rather than the current flow, which is lower because of withdrawals (see previous). In addition, if the flow from the San Joaquin River increased, the residence time of water within the Delta would substantially decrease. A decrease in the water residence time of the Delta would likely reduce the magnitude of the Delta 


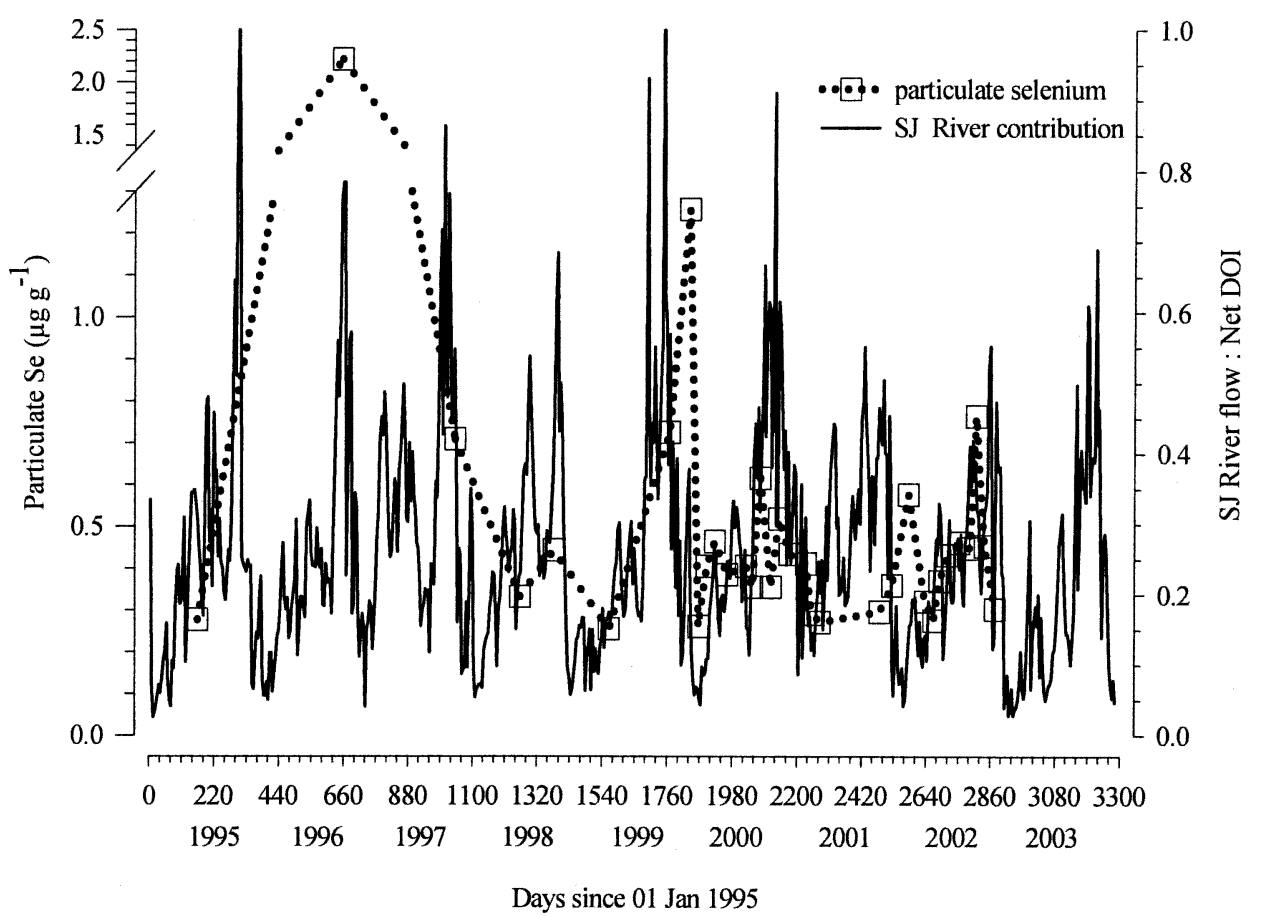

Fig. 9. Measured discharge from the San Joaquin River at Vernalis relative to the total net flow from the Delta (SJ River Flow: Net DOI) compared to particle associated selenium at a fixed site in Suisun Bay $\left(38^{\circ} 1.89^{\prime} \mathrm{N}, 122^{\circ} 8.39^{\prime} \mathrm{W}\right)$ over a nine year period. The SJ River Flow: Net DOI total net flow (Net DOI) is a ratio of the San Joaquin river discharge to the net delta outflow where Net DOI is defined as the total freshwater discharge from the Delta.

removal constant described previously. Therefore, simulations were run for both overall high and low flow months (driven by the Sacramento River) under the following conditions: normal flow from the San Joaquin River (including withdrawals) as used in the validations, high San Joaquin River discharge (i.e., discharge from Vernalis with no withdrawals) with the Delta removal constant still turned on, and high San Joaquin River discharge with the Delta removal constant turned off (i.e., extremes of potential residence time effects).

During a high flow month (April) total dissolved selenium in the estuary displayed nonconservative behavior under current conditions, and increasing the flow from the San Joaquin River and removing the Delta removal constant of $60 \%$ did not change the general shape of the total dissolved selenium profile (Fig. 7A). However, under current conditions the model predicted a maximum of $1.8 \mathrm{nmol} \mathrm{L}^{-1}$ at a salinity of 5 , whereas under high San Joaquin River flow the maximum increased to $2 \mathrm{nmol} \mathrm{L}^{-1}$ and increased up to $3.2 \mathrm{nmol} \mathrm{L}^{-1}$ when the Delta removal constant was also turned off (Fig. 7A). For a low flow simulation (November), a mid-estuary peak was observed, and as the flow from the San Joaquin River increased, the mid-estuary selenium concentration maximum increased and moved closer to the river end members (Fig. 7B). As with high flow conditions, the model predicted the highest concentrations of dissolved selenium $\left(5.0 \mathrm{nmol} \mathrm{L}^{-1}\right)$ when the flow from Vernalis was increased and the Delta removal constant was turned off. This concentration is as high as those measured in the mid 1980s and 1990s (Cutter and
Cutter 2004) when refineries were discharging their greatest selenium concentrations.

Total particulate selenium profiles in April (high flow) showed that increasing the flow from the San Joaquin resulted in a slight increase of total particulate selenium in the estuary (Fig. 7C), whereas turning off the Delta removal constant had no effect on total particulate selenium (Fig. 7C; lines overlap). However, increasing the flow in the San Joaquin River during a low flow month (November) resulted in a maximum total particulate selenium concentration of $0.35 \mathrm{nmol} \mathrm{L}^{-1}$ with the Delta removal constant on, which is greater than the maximum total particulate selenium observed under current conditions $\left(0.25 \mathrm{nmol} \mathrm{L}^{-1}\right.$; Fig. 7D). Without the Delta removal constant, the total particulate selenium concentration maximum rose to $0.49 \mathrm{nmol} \mathrm{L}^{-1}$ (Fig. 7D).

The increased total particulate selenium could be caused by either an increase in sediment resuspension or in situ production of particles (i.e., via phytoplankton uptake). If the increase is due to sediment resuspension, the particleassociated selenium $\left(\mu \mathrm{g} \mathrm{g}^{-1}\right)$ should be similar for each simulation. In April there is no difference between the estuarine averages of particle-associated selenium for the three scenarios (Table 4), thus suggesting that the predicted increase in total particulate selenium is largely caused by sediment resuspension. However, when the simulation was run for November (low flow), particle-associated selenium concentration increased as more San Joaquin River water reached the bay (Table 4). When the Delta removal constant was turned off, the particulate-associated seleni- 
um exceeded $1 \mu \mathrm{g} \mathrm{g}^{-1}$ over a salinity range of 5 to 20 (Fig. 8). Significantly, this concentration of particle-associated selenium is one that has a direct effect on consumer organisms, such as clams, and higher trophic levels in the estuarine food web (Luoma et al. 1992). These simulation results (Figs. 7, 8; Table 4) show that the concentration of particle-associated selenium varies with the different flow scenarios, suggesting that these changes are attributed to in situ production of particulate selenium (by phytoplankton) and not just sediment resuspension. Although the model has been validated under past and present conditions (i.e., excellent accuracy), these low flow (November) predictions are rather surprising. Essentially, the model predicts higher suspended particulate selenium in the upper estuary during higher San Joaquin discharge rates. In support of this prediction, field data from a fixed site in Suisun Bay across a 7-year, albeit discontinuous, period (Fig. 9) show a positive San Joaquin River flow-particulate selenium trend $\left(r^{2}=0.633, n=27\right)$, although the flows and concentrations are not always in phase.

Altered refinery inputs-In 1986, the refineries were discharging $99 \mathrm{~mol} \mathrm{~d}^{-1}$ of total selenium with $64 \%$ of the total as selenite (Cutter 1989), whereas in 1999 they were only discharging $38 \mathrm{~mol} \mathrm{~d}^{-1}$ with $13 \%$ as selenite, $57 \%$ as selenate, and $30 \%$ as organic selenide (Cutter and Cutter 2004). To examine how changing the refineries' discharges and speciation of selenium can affect selenium behavior (e.g., if they returned to higher discharge rates), three different flux rates using the current speciation (Cutter and Cutter 2004) were run: $38 \mathrm{~mol} \mathrm{~d}^{-1}$ as a reference (current conditions), $99 \mathrm{~mol} \mathrm{~d}^{-1}$ (old rate), and no discharge.

Under high flow (April) and low flow (November) conditions the predicted estuarine behaviors for total dissolved selenium were apparently nonconservative (Fig. 10A,B). During a high flow month, varying the refinery discharge from $0 \mathrm{~mol} \mathrm{~d}^{-1}$ to $99 \mathrm{~mol} \mathrm{~d}^{-1}$ resulted in the total dissolved selenium maxima ranging from $1.0 \mathrm{nmol} \mathrm{L}-1$ to $2.2 \mathrm{nmol} \mathrm{L}^{-1}$ (Fig. 10A). In November (low flow month), total dissolved selenium concentrations increased to a maximum of $2.8 \mathrm{nmol} \mathrm{L}^{-1}$ as the refinery inputs increased (Fig. 10B). Under pristine conditions (no refinery inputs), total dissolved selenium had no midestuary maximum, compared to when the refineries were discharging selenium (Fig. 10B).

The model predicted no change in total particulate selenium within the estuary due to an increase/decrease in refinery inputs during a high flow month (Fig. 10C). However, for a low flow month (November) total particulate selenium increased when the refinery discharge was increased (Fig. 10D). Any increase in total particulate selenium must be caused by in situ production since the discharge from the refineries has no effect on the amount of sediment resuspended in the bay. The estuarine average particle-associated selenium increased from $0.43 \mu \mathrm{g} \mathrm{g}^{-1}$ under pristine conditions to $0.62 \mu \mathrm{g} \mathrm{g}^{-1}$ with the highest refinery inputs (Table 4). This is below the $1 \mu \mathrm{g} \mathrm{g}^{-1}$ of particle-associated selenium that has caused elevated concentrations of selenium in tissues of benthic consumers

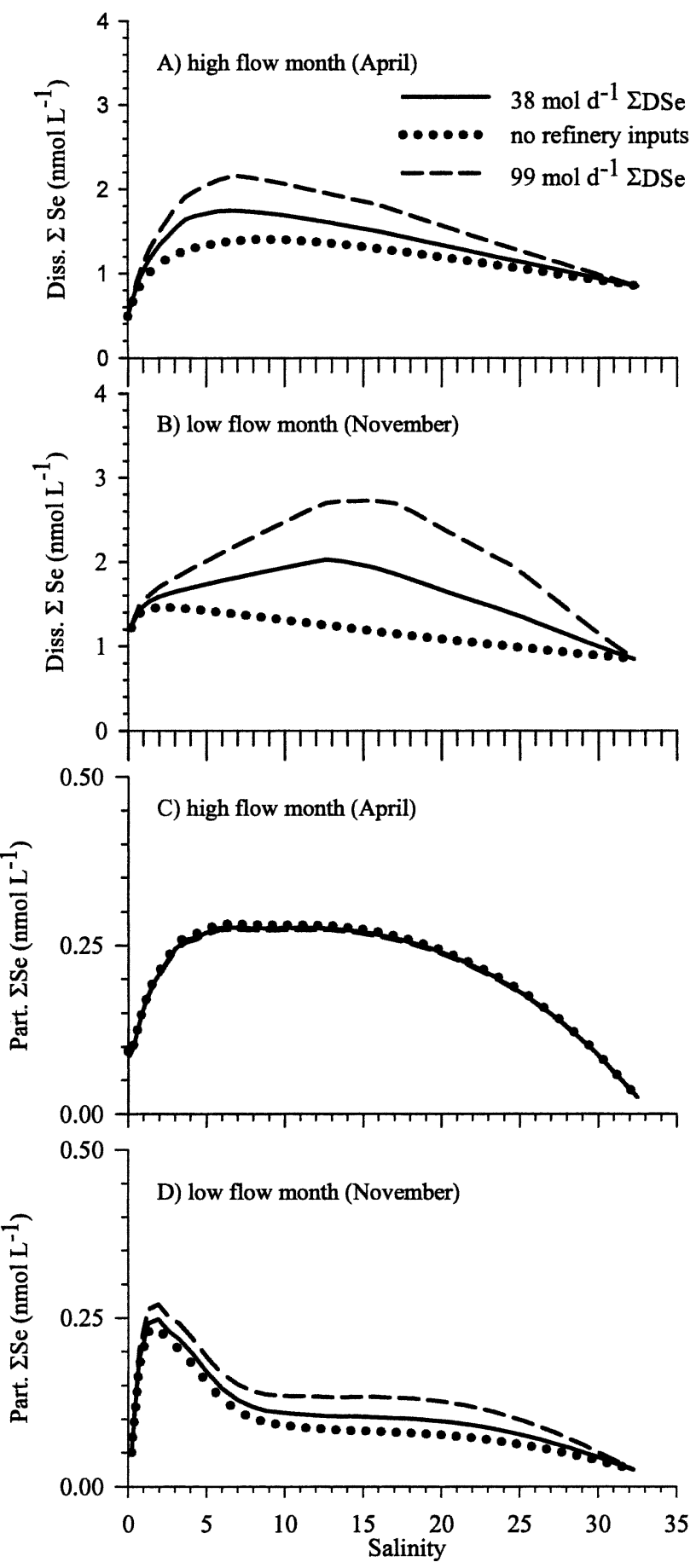

Fig. 10. (A) Model predictions for total dissolved selenium during a high flow month and (B) a low flow month and (C) total particulate selenium for a low flow month and (D) a high flow month in the San Francisco Bay under varying refinery discharge rates. The total discharge rates $(38 \mathrm{~mol}$ total dissolved selenium $\mathrm{d}^{-1}$ and 99 mol total dissolved selenium $\mathrm{d}^{-1}$ ) were from all the refineries in Fig. 2 with $13 \%$ of the total as selenite, $57 \%$ of the total as selenate, and $30 \%$ of the total as organic selenide.

(Luoma et al. 1992; Luoma and Rainbow 2005), but is still above the typical background levels $\left(0.2 \mu \mathrm{g} \mathrm{g}^{-1}\right.$; Doblin et al. 2006). 


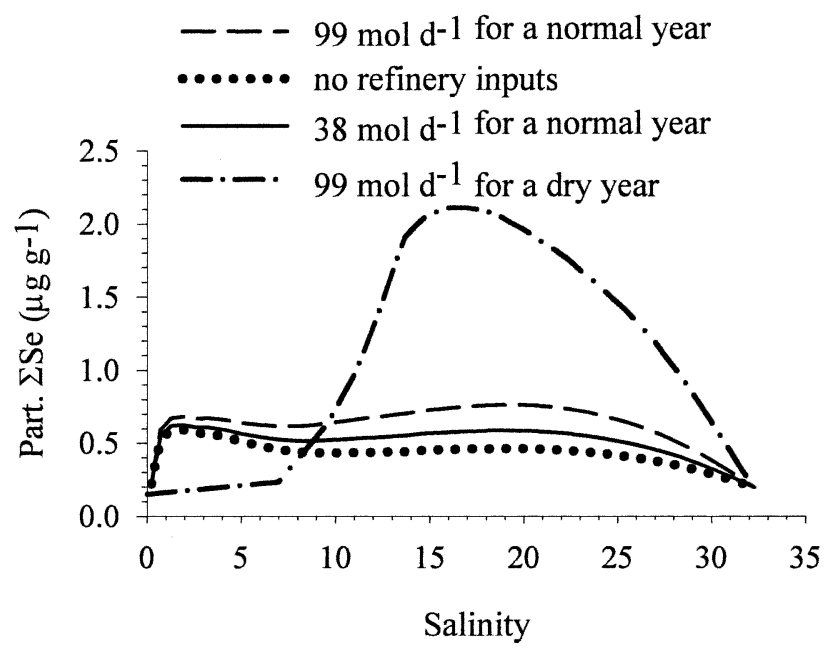

Fig. 11. Model predictions for particle-associated selenium in San Francisco Bay when selenium discharges from refineries are varied under normal river flow conditions and during a dry year. The total discharge rates $\left(38 \mathrm{~mol}\right.$ total dissolved selenium $\mathrm{d}^{-1}$ and 99 mol total dissolved selenium $\mathrm{d}^{-1}$ ) were from all the refineries in Fig. 2 with $13 \%$ of the total as selenite, $57 \%$ of the total as selenate, and $30 \%$ of the total as organic selenide.

Although it might seem that refinery discharge has only a minor effect, it should be remembered that these simulations were run under a normal flow year (when summer discharge is $<400 \mathrm{~m}^{3} \mathrm{~s}^{-1}$, but $>200 \mathrm{~m}^{3} \mathrm{~s}^{-1}$ ). According to the hydrological classification of the San Francisco Bay estuary in the last 20 years (1983-2003), five have been dry years and five have been critical (i.e., drought) conditions. If the simulation were run using the flow from a critical year (1977) and the higher refinery inputs $\left(99 \mathrm{~mol} \mathrm{~d}^{-1}\right)$, the model predicted particle-associated selenium could reach a maximum of $2.2 \mu \mathrm{g} \mathrm{g}^{-1}$ (Fig. 11). This is greater than what would occur if the flow from the San Joaquin River was increased, indicating that the effects from the refineries are magnified depending on the freshwater residence time in the estuary (Cutter 1989; Cutter and San Diego-McGlone 1990).

The confidence associated with the ability of the model to predict future scenarios is dependent on how well known each parameter in the model is and the number of validation runs that can be done. The model results indicate that in situ processes (phytoplankton uptake of selenium and adsorption/desorption of selenite and selenate) need better parameterization. In particular, the uptake rates of different dissolved selenium forms by relevant estuarine phytoplankton species need to be quantified using Michaelis-Menton kinetics. As an example, recent studies within the Delta (Baines et al. 2004) found the biotic uptake rate of dissolved organic selenide may be much faster than previously thought.

The model simulations under various scenarios of San Joaquin River flow also show the need for studies of selenium reactivity as it is transported from Vernalis, through the Delta, to the bay. For example, sensitivity analysis found that varying the Delta removal constant by only $25 \%$ could result in an increase of dissolved selenate within the estuary by $51 \%$ and particulate organic selenium could increase by $16 \%$ within the estuary (Web Appendix 2 ). If selenium concentration measured by Cutter and Cutter (2004) at Vernalis were to be introduced to the estuary, the particle-associated selenium would be $>1 \mu \mathrm{g} \mathrm{g}^{-1}$ and have cascading effects through the estuarine food web (Luoma and Rainbow 2005). Finally, the model provides an excellent demonstration of the effect that reducing refinery inputs has on the concentrations of dissolved and particulate selenium under conditions seldom found in empirical studies (e.g., extremes of river flows; Cutter 1989; Cutter and Cutter 2004).

Although the model applications described here were specific for selenium and the San Francisco Bay, the steps for adapting ECoS 3 were not. For example, the processes depicted in Fig. 1 and incorporated into the model could be used to simulate the behavior of arsenic in San Francisco Bay by adjusting or eliminating some of the transformation and uptake rate constants, in addition to adjusting the concentrations of inputs; all of the physical processes are the same. The model also could be used for studying selenium in another well mixed estuary, for example Delaware Bay. In this application, the physical parameters such as those for tides and bathymetry would have to be adjusted, as well as the phytoplankton growth and grazing parameters, but not those for selenium. Regardless of the element or venue, the full integration of large data sets and biogeochemical models of estuaries such as San Francisco Bay enable an expanded understanding of estuarine processes and simulations of effects that could result from water/ecosystem management decisions.

\section{References}

Baines, S. B., N. S. Fisher, M. A. Doblin, and G. A. Cutter. 2001. Uptake of dissolved organic selenides by marine phytoplankton. Limnol. Oceanogr. 46: 1936-1944.

$-\longrightarrow,-,-$ AND L. S. CutTer. 2004. Light dependence of selenium uptake by phytoplankton and implications for predicting selenium incorporation into food webs. Limnol. Oceanogr. 49: 566-578.

Belzile, N., AND J. Lebel. 1988. Selenium profiles in the sediments of the Laurentian trough (Northwest North Atlantic). Chem. Geo. 68: 99-103.

Cloern, J. E., And A. Alpine. 1991. Potamocorbula amurensis, a recently introduced Asian clam, has had dramatic effects on the phytoplankton biomass and production in northern San Francisco Bay. J. Shellfish Re. 10: 258-259.

, B. E. Cole, L. Raymond, J. Wong, and A. E. Alpine. 1985. Temporal dynamics of esturine phytoplankton: A case study of San Francisco Bay. Hydrobiologia 129: 153-176.

Cole, B. E., And J. E. Cloern. 1984. Significance of biomass and light availability to phytoplankton productivity in San Francisco Bay. Mar. Ecolo. Prog. Ser. 17: 15-24.

Cooke, T. D., and K. W. Bruland. 1987. Aquatic chemistry of selenium: Evidence of bimethylation. Environ. Sci. Technol. 21: $1214-1219$.

Cutter, G. A. 1989. The estuarine behaviour of selenium in San Francisco Bay. Estuar. Coast. Shelf Sci. 28: 13-34.

. 1992. Kinetic controls on metalloid speciation in seawater. Mar. Chem. 40: 65-80. 
, AND K. W. BRULAND. 1984. The marine biogeochemistry of selenium in a simple system. Geochim. Cosmochim. Acta 48: 1417-1433.

, AND L. S. CutTer. 2004. Selenium biogeochemistry in the San Francisco Bay estuary: Changes in water column behavior. Estuar. Coast. Shelf Sci. 6: 463-476.

—, And M. L. C. SAn Diego-McGlone. 1990. Temporal variability of selenium fluxes in the San Francisco Bay. Sci. Total. Environ. 97: 235-250.

Doblin, M. A., S. Baines, L. S. Cutter, and G. A. Cutter. 2006. The biogeochemistry of selenium in San Francisco Bay estuary: seston and phytoplankton. Est. Coastal Shelf Sci 67: 681-694.

Doblin, M. A., S. I. Blackburn, and G. M. Hallegraeff. 1999. Comparative study of selenium requirements of three phytoplankton species: Gymnodinium catenatum, Alexandrium minutum (Dinophyta) and Chaetoceros cf. tenuissimus (Bacillariophyta). J. Plankton Res. 21: 1153-1169.

Harris, J. R. W., and R. N. Gorley. 1998. An introduction to modeling estuaries with ECoS 3. Plymouth Marine Laboratory.

Lehman, P. W. 2000. The influence of climate on phytoplankton community biomass in San Francisco Bay Estuary. Limnol. Oceanogr. 45: 580-590.

Lucas, L. V., J. E. Cloern, J. R. Koseff, S. G. Monismith, and K. J. Thompson. 1998. Does the Sverdrup critical depth model explain bloom dynamics in estuaries? J. Mar. Res. 56: 375-415.

Luoma, S. N., C. Johns, N. S. Fisher, N. A. Steinberg, R. S. OREMLAND, AND J. R. ReINFELDER. 1992. Determination of selenium bioavailability to a benthic bivalve from particulate and dissolved pathways. Environ. Sci. Technol. 26: 485-491.

Luoma, S. N., P. S. Rainbow, 2005. Why is metal bioaccumulation so variable? Biodynamics as a unifying concept. Environ. Sci. Technol. 39: 1921-1931.

Measures, C. I., R. E. McDuff, And J. M. Edmonds. 1980. Selenium redox chemistry at GEOSECS 1 re-occupation. Earth Planet Sci. Lett. 29: 120.

Mwanuzi, F., and F. De Smedt. 1999. Heavy metal distribution model under estuarine mixing. Hydrol. Process. 13: 789-804.

Nyffeler, U. P., Y. H. Li, and P. H. Santshi. 1984. A kinetic approach to describe trace-element distribution between particles and solution in natural systems. Geochim. Cosmochim. Acta 48: 1513-1522.

Ohlendorf, H. M., R. W. Lowe, P. R. Kelly, and T. E. Harvey. 1986. Selenium and heavy metals in San Francisco diving ducks. J. Wildl. Manage. 50: 64-71.

Oremland, R. S., J. T. Hollibaugh, M. A. Maest, T. S. Presser, L. G. Miller, and C. W. Culbertson. 1989. Selenate reduction to elemental selenium, by anerobic bacteria in sediments and cultures: Biogeochemical significance of a novel, sulfate-independent respiration. Appl. Environ. Microbiol. 55: 2333-2343.

Paucot, H., AND R. Wollast. 1997. Transport and transformation of trace metals in the Scheldt Estuary. Mar. Chem. 58: 229-244.

Perrin, C., C. Michel, and V. Andréassian. 2001. Does a large number of parameters enhance model performance? Comparative assessment of common catchments model structures on 429 catchments. J. Hydrol. 242: 275-301.

Platt, T., AND A. D. JASSBY. 1976. The relationship between photosynthesis and light for natural assemblages of coastal marine phytoplankton. J. Phycol. 12: 421-430.

Presser, T. S., AND D. Z. Piper. 1998. Mass balance approach to selenium cycling through the San Joaquin Valley, sources to river to Bay, p. 153-182. In W. Grankenberger and R. A. Engberg [eds.], Environmental chemistry of selenium. Marcel Dekker.

Riedel, G. F., J. G. Sanders, And C. C. Gilmour. 1996. Uptake, transformation, and impact of selenium in freshwater phytoplankton and bacterioplankton communities. Aquat. Microb. Ecol. 11: 43-51.

Stewart, A. R., S. N. Luoma, C. E. Schlekat, M. A. Doblin, AND K. A. Hieb. 2004. Foodweb pathway determines how selenium affects aquatic ecosystems: A San Francisco Bay case study. Environ. Sci. Technol. 38: 4519-4526.

Takayanagi, K., and D. Cossa. 1985. Speciation of dissolved selenium in the upper St. Lawrence Estuary, p. 275-284. In A. C. Siglo and A. Hatteri [eds.], Marine and estuarine geochemistry. Lewis Publishers.

Thompson, J. K. 2000. Two stories of phytoplankton control by bivalves in San Francisco Bay: The importance of spatial and temporal distribution of bivalves. J. Shellfish Res. 19: 612.

VAndermeulen, J. H., AND A. FodA. 1988. Cycling of selenite and selenate in marine phytoplankton. Mar. Biol. 98: 115-123.

Velinsky, D. J., And G. A. Cutter. 1991. Geochemistry of selenium in a coastal salt marsh. Geochem. Cosmochim. Acta 55: 179-191.

Werner, I., AND J. T. Hollibaugh. 1993. Potamocorbula amurensis: Comparison of clearance rates and assimilation efficiencies for phytoplankton and bacterioplankton. Limnol. Oceanogr. 38: 949-964.

Zhang, Y., And J. N. Moore. 1996. Selenium fractionation and speciation in a wetland sediment. Env. Sci. Technol. 30: 2613-2619.
Received: 29 August 2005 Accepted: 6 March 2006 Amended: 10 April 2006 